\title{
Dissecting the mechanisms involved in anti-human T-lymphocyte immunoglobulin (ATG)-induced tolerance in the setting of allogeneic stem cell transplantation - potential implications for graft versus host disease
}

\author{
Katia Beider ${ }^{1}$, David Naor ${ }^{2}$, Valeria Voevoda ${ }^{1}$, Olga Ostrovsky ${ }^{1}$, Hanna Bitner ${ }^{1}$, \\ Evgenia Rosenberg ${ }^{1}$, Nira Varda-Bloom ${ }^{1}$, Victoria Marcu-Malina ${ }^{1}$, Jonathan \\ Canaani ${ }^{1}$, Ivetta Danilesko ${ }^{1}$, Avichai Shimoni ${ }^{1}$ and Arnon Nagler ${ }^{1}$ \\ ${ }^{1}$ Hematology Division, Chaim Sheba Medical Center and Tel Aviv University, Tel-Hashomer, Ramat Gan, Israel \\ ${ }^{2}$ Lautenberg Center for Immunology and Cancer Research, Faculty of Medicine, Hebrew University of Jerusalem, Jerusalem, \\ Israel \\ Correspondence to: Arnon Nagler, email: a.nagler@sheba.health.gov.il \\ Keywords: ATG, Treg, TGFß, Immunology and Microbiology Section, Immune response, Immunity \\ Received: May 12, $2017 \quad$ Accepted: September 22, $2017 \quad$ Published: October 11, 2017 \\ Copyright: Beider et al. This is an open-access article distributed under the terms of the Creative Commons Attribution License 3.0 (CC BY \\ 3.0), which permits unrestricted use, distribution, and reproduction in any medium, provided the original author and source are credited.
}

\section{ABSTRACT}

Polyclonal anti-human thymocyte globulins (ATG) have been recently shown to significantly reduce the incidence of graft versus host disease (GVHD) post allogeneic stem cell transplantation (HSCT) from both sibling and unrelated donors. Induction of regulatory $\mathrm{T}$ cells has been suggested as one of the possible mechanisms. The aim of current study was to further characterize the $T$ cell populations induced by ATG treatment and to delineate the mechanisms involved in ATG-induced tolerance. Phenotypic characterization revealed a significant increase in the expression of FoxP3, GITR, CD95, PD-1 and ICOS as well as the complement inhibitory molecules CD55, CD58 and CD59 on CD4+CD25+ T cells upon ATG treatment. Addition of ATGtreated cells to autologous and allogeneic peripheral blood mononuclear cells (PBMCs) stimulated with anti-CD3/anti-CD28 antibodies resulted in significant inhibition of proliferation. Moreover, T-cell activation and IFNy secretion were reduced in the presence of ATG-induced Treg cells. The CD4+CD25+CD127-low Treg fraction sorted from ATG-treated culture demonstrated greater suppressive potency than negative fraction. Conditioned medium produced by ATG-treated but not IgG-treated cells contained TGF $\beta$ and suppressed T cell proliferation and activation in a TGF $\beta$ receptordependent manner. TGF $\beta$ receptor kinase inhibitor SB431542 interfered with the suppressive activity of ATG-primed cells, enabling partial rescue of proliferation and IFNy secretion. Moreover, SB431542 prevented Treg phenotype induction upon ATG treatment. Altogether, our data reveal the role of TGF $\beta$ signaling in ATGmediated immunosuppression and further support the use of ATG, a potent inducer of regulatory T cells, for prevention of GVHD post HSCT and potentially other therapeutic applications.

\section{INTRODUCTION}

Allogeneic hematopoietic stem cell transplantation (HSCT) is an established treatment for many hematological neoplasms including leukemia, lymphoma, and myeloma [1-5]. T cells and natural killer (NK) cells within the graft make the predominant contribution to graft-versus- tumor (GVT) activity [3, 6]. However, alloreactive donor immune cells are also responsible for one of the main reasons for transplant-related morbidity and mortality, namely graft-versus-host disease (GVHD) [7, 8]. In GVHD, recipient tissues are attacked by alloreactive donor non-regulatory effector CD4+ and CD8+ T cells $[9,10]$. Depletion of $\mathrm{T}$ cells from the allogeneic graft 
significantly reduces the incidence of GVHD, albeit at the price of delayed immune reconstitution [11], poorer donor-cell engraftment, as well as reduced GVT effect [12]. Accordingly, the goal of ongoing research is to preserve donor $\mathrm{T}$ cells in the graft, while concomitantly attempting to reduce donor T-cell-mediated acute and chronic GVHD [13]. CD4+CD25+FoxP3+ regulatory T cells (Tregs) comprise $5 \%$ to $10 \%$ of circulating CD4+ $\mathrm{T}$ cells. They are essential in maintaining peripheral self-tolerance and preventing inflammatory disease [1416]. Several studies have suggested that Tregs also play a central role in the establishment and maintenance of immune tolerance following HSCT. Indeed, depletion of CD25+ cells from splenocytes in a murine model resulted in increased GVHD severity and lethality after major histocompatibility complex-mismatched bone marrow transplantation, providing evidence that Tregs ameliorate the detrimental effects of alloreactive donor effector $\mathrm{T}$ cells in the host $[16,17]$. Similarly, Treg transplantation at high ratios could completely protect recipient mice from GVHD, even when lethal doses of effector T cells were administered $[17,18]$. Notably, clinical studies have demonstrated reduced CD4+FoxP3+ T-cell frequencies in the blood and in the mucosal tissues of patients with GVHD [19]. Recently, adoptive transfer of freshly isolated or in vitro-expanded Tregs from peripheral blood or cord blood was used in early clinical trials facilitating immune reconstitution with no increased risk of GVHD [2023]. Rabbit anti-thymocyte globulins (ATG- Fresenius) (Neovii-Biotech, Graefelfing, Germany) are a set of polyclonal antibodies (IgG fraction) directed against a variety of immune cell epitopes, purified from the serum of rabbits that were immunized with human $\mathrm{T}$ cells [24]. ATG is administered as part of the transplantation conditioning regimen to reduce the incidence and severity of GVHD by in vivo T-cell depletion. Due to their long half-life in human plasma (up to 6 weeks), ATG can persist in the blood for several weeks after infusion $[25,26]$ and induce apoptosis of donor $\mathrm{T}$ cells passively transferred with the graft. The beneficial effects of pre-transplant ATG for GVHD prevention have been demonstrated in several clinical studies [27-31]. Recently it was shown that pretransplant ATG selectively depletes donor naive T cells and central memory CD4 $+\mathrm{T}$ cells, while it relatively preserves other $\mathrm{T}$ cell subsets. Specifically, Treg were not affected by pre-transplant ATG [32]. Since Treg cells can mediate immune tolerance $[33,34]$, their persistence might have also prevented GVHD.

The ability of ATG to promote Treg phenotype acquisition ex vivo has been demonstrated in previous studies. Thus, in vitro treatment with Thymoglobulin (rabbit anti-human ATG produced by immunization against thymocytes, Genzyme) efficiently induced the expression of Treg markers and provided suppressive activity to generated Treg cells [35-37]. Furthermore, our previous work demonstrated that ATG-F (produced by rabbit immunization against the human $\mathrm{T}$ lymphoblastoid cell line Jurkat, Neovii Biotech) promoted Treg cell generation in vitro, and suggested that ATG induces expansion of regulatory $\mathrm{T}$ cells in patients undergoing allogeneic HSCT [38]. However, there are controversial data with regard to the potential of ATG to promote expression of regulatory phenotype in T cells. Thus, Broady et al. demonstrated transient up-regulation of Foxp3 expression upon ATG treatment without the acquisition of suppressive potential that was related to activated rather than suppressive phenotype [39]. Therefore, it is important to re-evaluate the effects of ATG in regulatory phenotype induction and to determine the mechanisms underlying this activity. Our work demonstrates that in vitro treatment with ATG is capable of inducing functional Treg cells. The suppressive ability of ATG-induced cells is both contact and solublefactors dependent and is partially promoted by TGF $\beta$ signaling. Altogether, our data further support the use of ATG-F, a potent inducer of Treg cells, for prevention of GVHD post HSCT and potentially for other therapeutic applications.

\section{RESULTS}

\section{ATG induces Treg phenotype acquisition in CD4+ T cells}

First, to assess the effect of in vitro ATG treatment on T cell phenotype, freshly purified PBMCs from healthy donors were exposed during 48 hours to ATG $(60 \mu \mathrm{g} /$ ml) (Neovii-Biotech, Graefelfing, Germany) or to rabbit IgG as a control. Pharmacokinetics studies [40] suggest that chosen in vitro ATG concentration $(60 \mu \mathrm{g} / \mathrm{ml})$ is achievable in patients administered with $30 \mathrm{mg} / \mathrm{kg}$ [31] or $60 \mathrm{mg} / \mathrm{kg}$ ATG-F [28]. Markers associated with Treg phenotype were evaluated by flow cytometry. As shown in Figure 1A, ATG treatment induced marked increase in the frequency of CD4+CD25+CD127-low Treg population in culture. Moreover, expression of Treg markers FoxP3, CD95, GITR, PD-1 and ICOS was significantly increased on the gated CD4+CD25+ cells following the treatment with ATG compared with IgG treatment (Figure 1B, 1C). In addition, ATG treatment up-regulated the expression of complement inhibitory receptors CD55, CD58 and CD59 on the surface of CD4+CD25+ cell subset. These findings were consistent in all samples from different donors $(n$ $=4$ ) that were analyzed and indicated the acquisition of Treg phenotype in CD4+ T cells upon exposure to ATG in vitro. The increase in the expression of complement inhibitory receptors following ATG treatment suggests the reduced sensitivity of generated Treg cells to complementdependent cytotoxicity.

To evaluate the stability of the acquired Treg phenotype, PBMCs were exposed to ATG for 48 hours, 


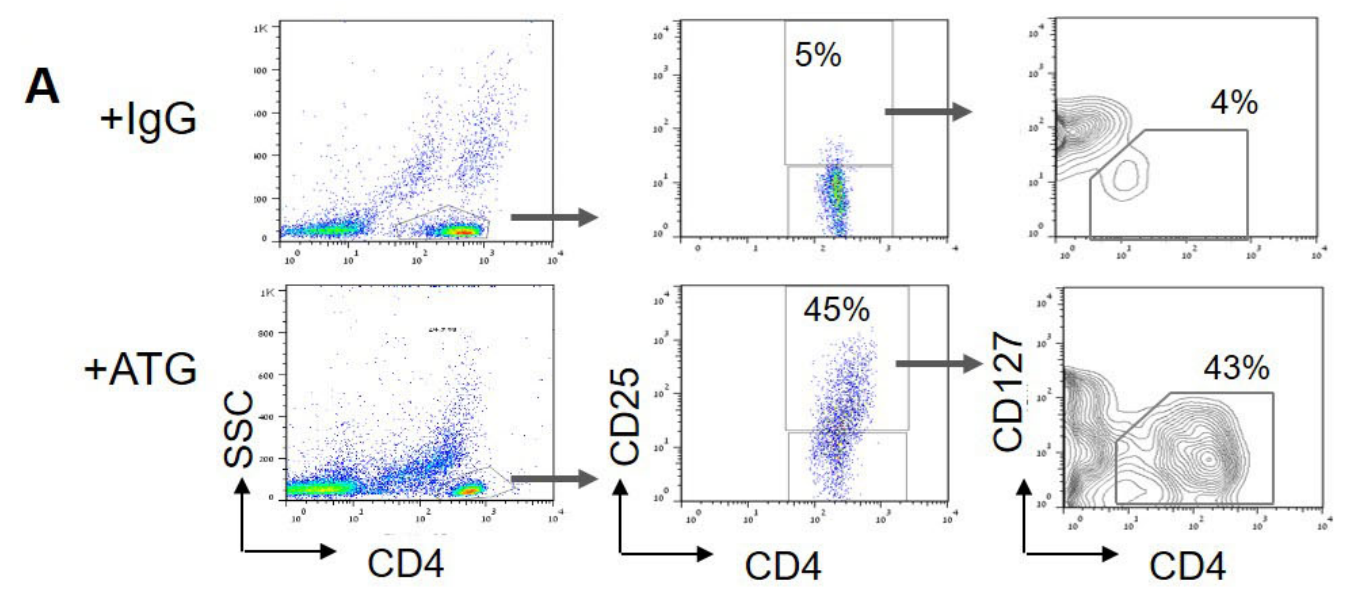

B $\quad \underline{\text { CD4+CD25+ subset } \quad \text { - IgG-treated }}$
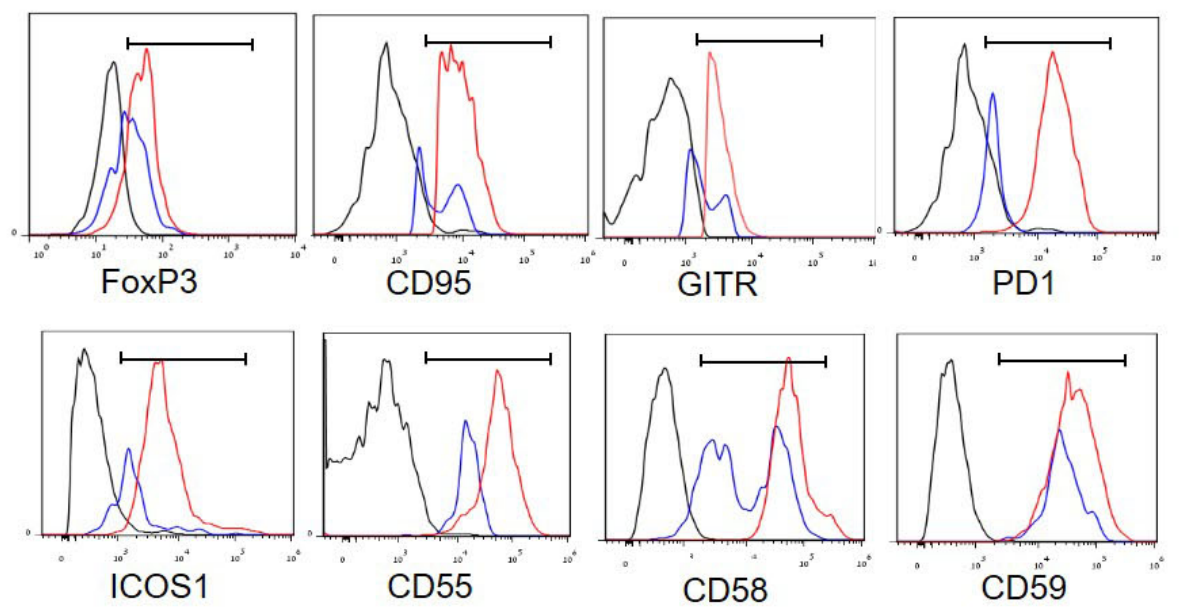

C
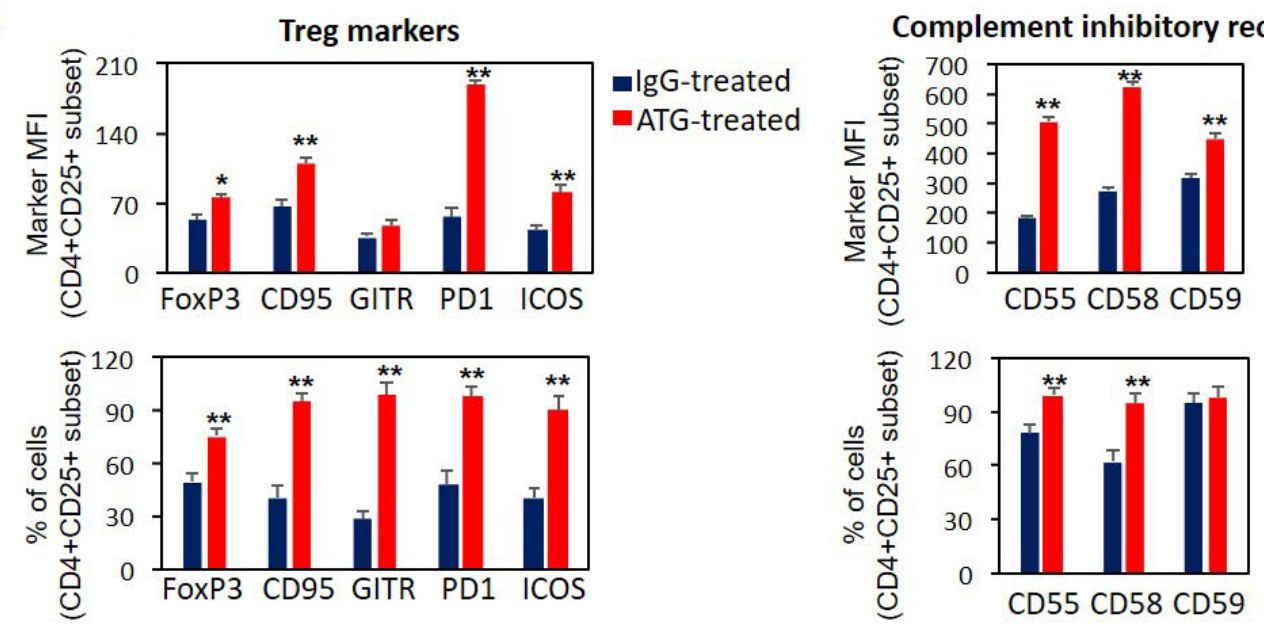

Figure 1: ATG treatment induces the expression of Treg markers and complement inhibitory receptors. Normal PBMCs were incubated during 48 hours with ATG $(60 \mu \mathrm{g} / \mathrm{ml})$ or rabbit IgG. Cell surface staining for CD4, CD25, CD127, CD95, GITR, ICOS, PD1, CD55, CD58, CD59 and intra-cellular staining for FoxP3 was performed. A. Representative plots showing CD25 and CD127 expression on gated CD4+ cells. CD4+CD25+CD127-low subset of Treg cells is enumerated. B. Representative histograms showing the expression of Treg markers and complement inhibitory receptors in the CD4+CD25+ cell subset. C. Mean fluorescence intensity (MFI) and percentage of $\mathrm{CD} 4+\mathrm{CD} 25+$ cells expressing the specific markers are presented as mean of triplicates $\left({ }^{*} p<0.01\right)$. Data are representative of four independent experiments. 
then ATG was removed and the cells were washed and re-plated for an additional 48 hours. As shown in Figure 2, ATG removal resulted in a subsequent decrease in Treg markers expression, including CD25 and FoxP3 downregulation and up-regulation of CD127. This reversion was not simply related to the prolonged culture time, since the cells incubated for the same period of 96 hours with the continuous exposure to ATG demonstrated stable Treg phenotype (Figure 2A, 2B). Therefore, we can conclude that ATG-mediated Treg induction is a reversible phenomenon and the presence of ATG is necessary to promote and preserve this effect. However, taking into account the long half-life time of ATG in the serum (elimination half-life of 30 days [41]) one can suggest that ATG persistence before and during the first weeks after allogeneic HSCT will enable Treg generation which may decline as ATG serum levels decrease.

\section{ATG-induced Treg cells suppress autologous T cell proliferation}

Next, the functional properties of ATG-induced Treg (iTreg) cells were tested. To evaluate the suppressive potential of induced Treg cells, ATG-treated cells were applied to the proliferation assay of autologous PBMCs
A

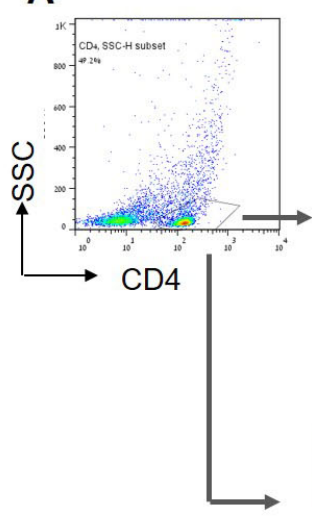

CD4+ CD25+ subset
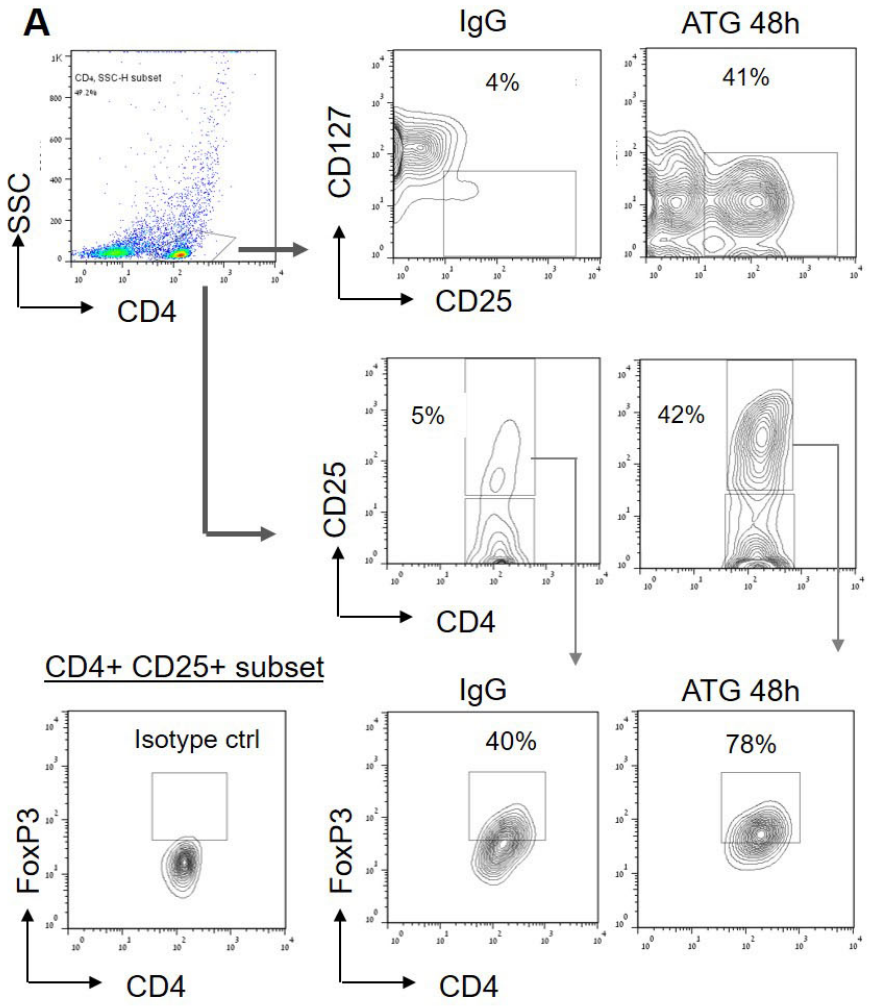

ATG $48 \mathrm{~h}+$ wash, $48 \mathrm{~h}$ culture
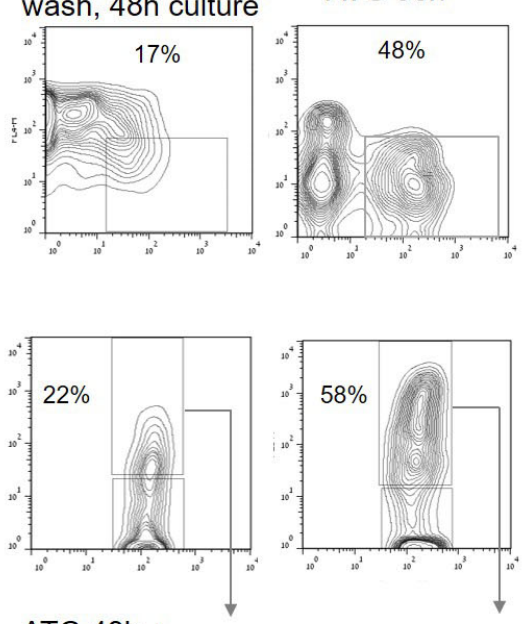

ATG $48 \mathrm{~h}+$ wash, $48 \mathrm{~h}$ culture
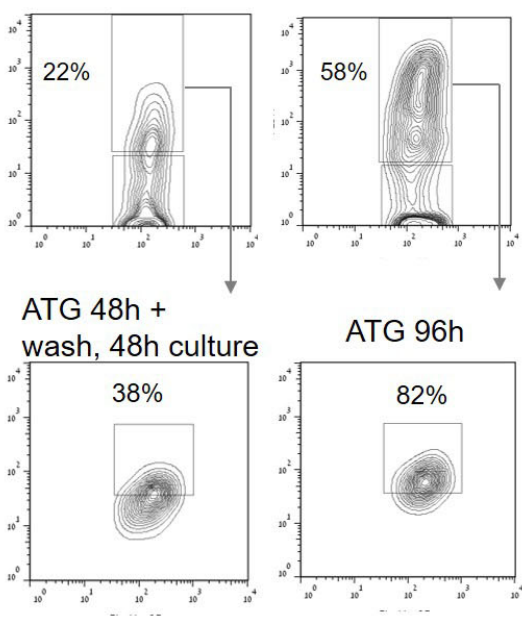

B
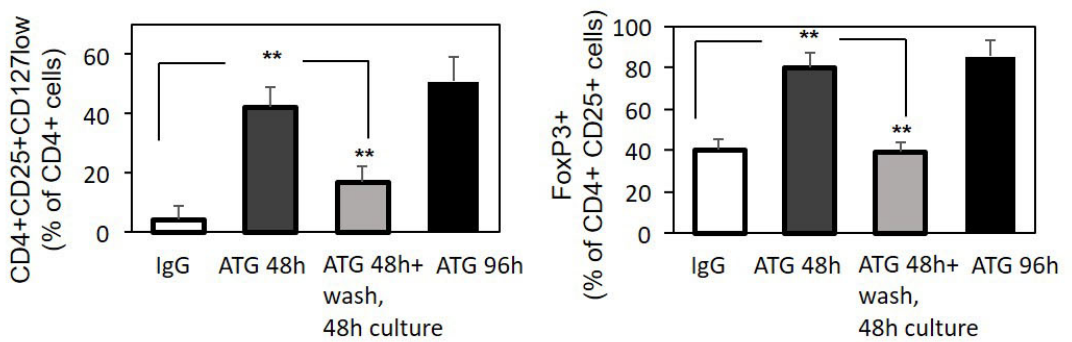

Figure 2: ATG-mediated induction of Treg phenotype is reversible. PBMCs were incubated for 48 hours or 96 hours with ATG $(60 \mu \mathrm{g} / \mathrm{ml})$ or rabbit IgG. Alternatively, PBMCs were exposed to ATG for 48 hours, then ATG was removed, cells were washed with PBSx1 three times and re-plated in fresh medium without ATG for additional 48 hours. Cells were analyzed by flow cytometry for CD4, CD25, CD127 and FoxP3 expression. A. Representative plots demonstrating the frequency of CD4+CD25+CD127low and CD4+CD25+FoxP3+ Treg cells following the treatments. B. Percentage of CD4-positive cells co-expressing high CD25 and low CD127 (left panel), or high CD25 and high FoxP3 (right panel) presented as mean of triplicates $\pm \operatorname{STDEV}(* * p<0.01)$. 
stimulated with anti-CD3/anti-CD28 soluble antibodies. A proliferative response of gated CD3-positive cells was measured using CFSE dye dilution method and by testing Ki67 marker expression. As demonstrated in Figure 3, addition of ATG-treated iTreg cells but not of IgGtreated control cells resulted in significant suppression of autologous T cell proliferation, decreasing the percent of CFSE-low and Ki67-positive cells, respectively (Figure 3A, 3B). Accordingly, ATG-treated iTreg cells but not IgG-treated control cells were capable of reducing the expression of $\mathrm{T}$ cell activation marker CD69 by 50-60\% upon CD3/CD28 stimulation (Figure 3C). Furthermore,
A non-stimulated

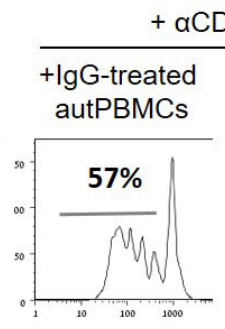

$+\alpha C D 3 / a C D 28$

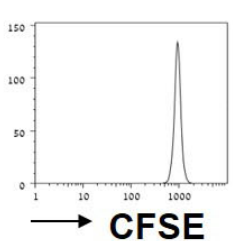

B non-stimulated

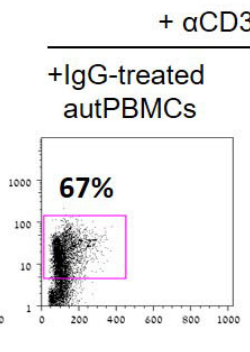

$+\alpha C D 3 / a C D 28$
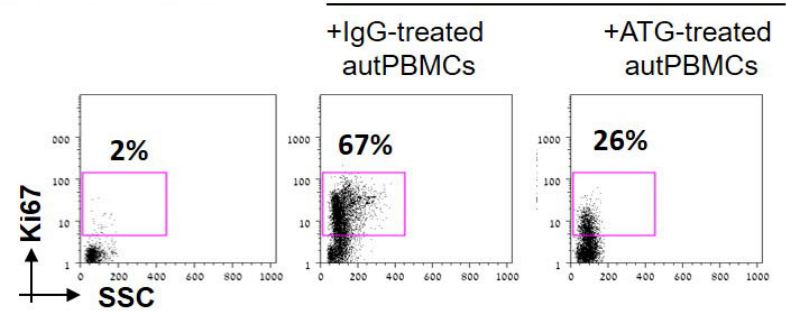

C non-stimulated

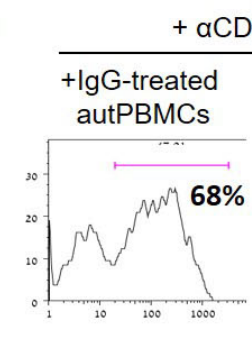

$+a C D 3 / a C D 28$
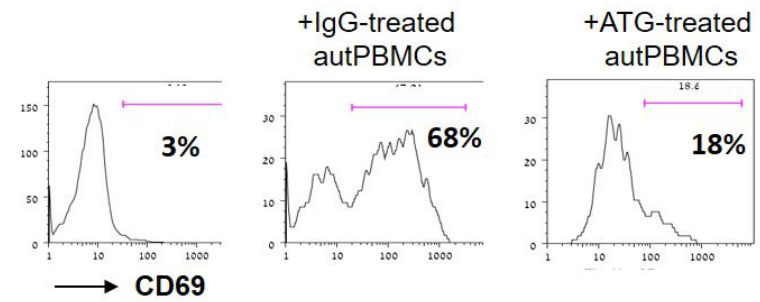

D

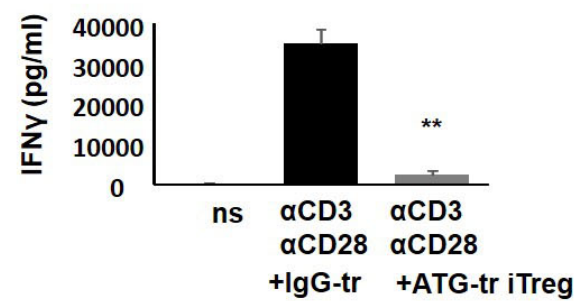

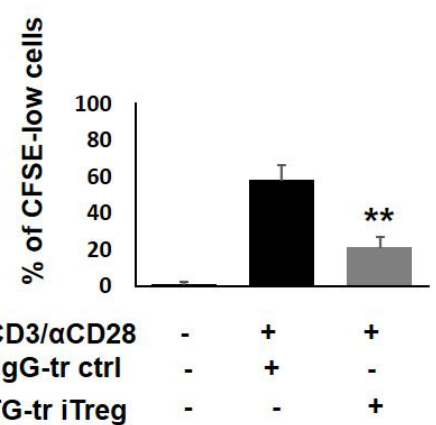

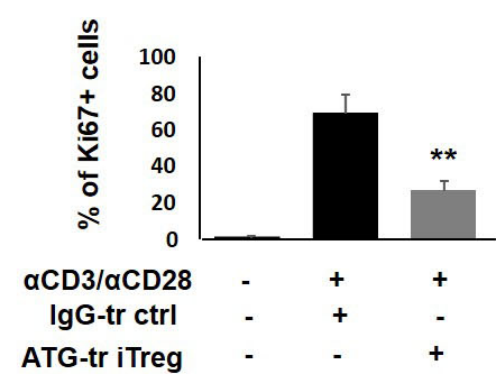

ATG-tr iTre

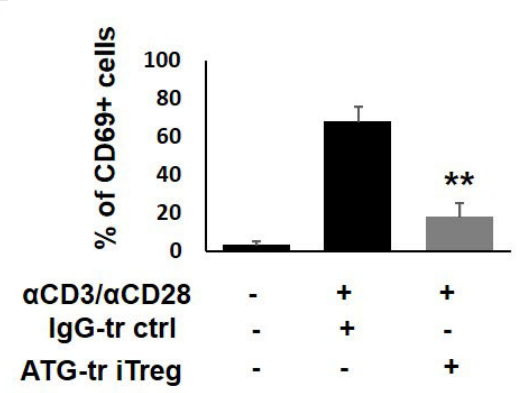

Figure 3: ATG-induced Treg cells suppress T cell proliferation and activation. PBMCs were stimulated with anti-CD3/antiCD28 antibodies, in the presence of autologous ATG- or rabbit IgG-pretreated cells (at 1:1 ratio), for 5 days of incubation. Suppressive effect of ATG-induced Treg-enriched cells on proliferation was measured by CFSE dilution method A. or by Ki67 expression B. Percentage of proliferated CD3 + T cells is shown as mean of triplicates $\pm \operatorname{STDEV}(* * p<0.01)$. Data are representative of three independent experiments. C. Percentage of CD3-positive cells expressing the activation marker CD69 at day 5 of stimulation, presented as mean of triplicates \pm STDEV $(* * p<0.01)$. Left panes of A, B and C shows representative staining plots, while right panels show the percentage of proliferated or activated cells. D. IFN $\gamma$ levels at day 5 of stimulation in the conditioned medium were determined by ELISA, presented as mean of triplicates $\pm \operatorname{STDEV}(* * p<0.01)$. $\operatorname{Tr}=$ treated. 
the secretion of the pro-inflammatory cytokine IFN $\gamma$ in response to $\mathrm{CD} 3 / \mathrm{CD} 28$ stimulation was nearly fully abrogated in the presence of ATG-treated iTreg cells (Figure 3D). These findings indicate that ATG-induced Treg cells are functionally competent and capable of suppressing the proliferation and activation of autologous T cells.

\section{CD8+ effector $T$ cells are the most sensitive to ATG-induced Treg cell-mediated suppression}

Next, we wanted to delineate the response of specific T cell subsets to ATG-iTreg-mediated suppression. Therefore, the differential response of CD3+CD4+ $\mathrm{T}$ helper and CD3+CD8+ T effector cells to iTreg-mediated suppression of proliferation was evaluated. Interestingly, the most profound suppressive effect was detected in $\mathrm{CD} 8+$ effector population, reducing the percent of $\mathrm{Ki} 67-$ positive proliferating cells from $47 \%( \pm 7 \%)$ in control group to $8 \%( \pm 3 \%)$, thus resulting in an $83 \%$ proliferation reduction $(* * p<0.01)$ following the co-culture with ATG iTreg cells. In comparison to CD8+ effector cells, CD4+ $\mathrm{T}$ helper cells demonstrated lower initial proliferative rates in response to $\mathrm{CD} 3 / \mathrm{CD} 28$ activation $(25 \% \pm 3 \%$ in control group) and were less responsive to iTreg-mediated suppression, showing $15 \% \pm 5 \%$ proliferation, and thus $40 \%$ suppression $(* p<0.05)$. The remaining CD4negative CD8-negative non-T cells were barely activated by $\mathrm{CD} 3 / \mathrm{CD} 28$ stimulation and were not affected by the iTreg cell (Figure 4).
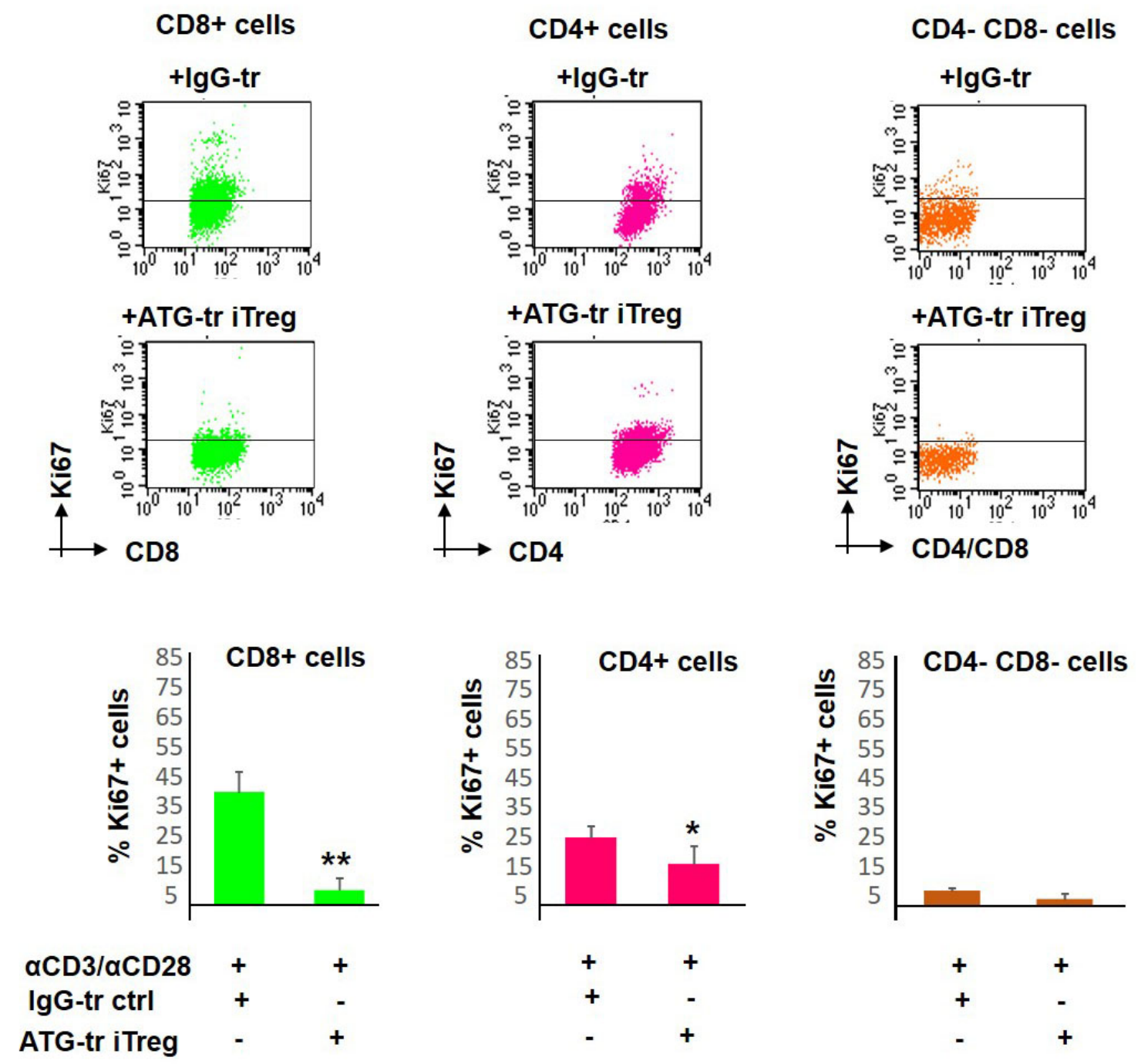

Figure 4: Proliferative response of different $\mathbf{T}$ cell subsets. PBMCs were stimulated with anti-CD3/anti-CD28 antibodies, in the presence of autologous ATG- or rabbit IgG-pretreated cells (at 1:1 ratio), for 5 days of incubation. Proliferation of CD8-positive, CD4positvie or CD4/CD8-negativie cells was determined by Ki67 expression. Representative plots showing Ki67 expression in specific cell sub-populations. Suppressive potential of ATG-induced Treg cells on different sub-populations, percentage of proliferated cells is presented as mean of triplicates $\pm \mathrm{STDEV}$ at the lower panels $\left({ }^{*} p<0.05,{ }^{*} p<0.01\right)$. Data are representative of three independent experiments. Tr $=$ treated. 
ATG-induced Treg cells are able to suppress both autologous and allogeneic cell proliferation

Our next goal was to evaluate whether the suppressive effect of ATG-induced Treg cells is restricted to autologous cells or whether it could be extended to allogeneic T cells as well. Indeed, in addition to autologous cells, we observed a potent suppressive effect mediated by ATG-treated Treg cells against allogeneic effector T cells stimulated with anti-CD3/anti-CD28 antibodies that was comparable with inhibition of autologous $\mathrm{T}$ cells (Figure $5)$.

A

A isotype ctrl

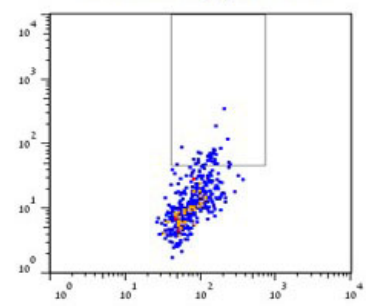

B isotype ctrl

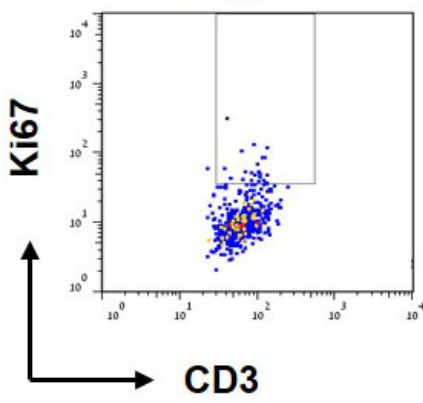

A+A-IgG

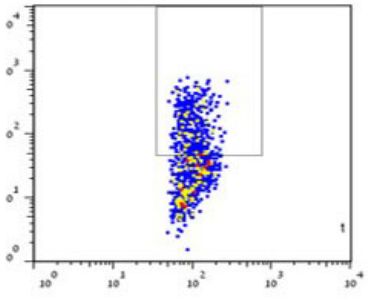

$B+A-\lg G$

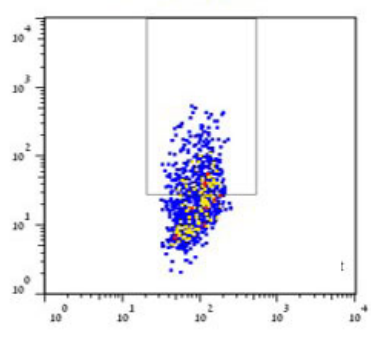

A+A-ATG-60

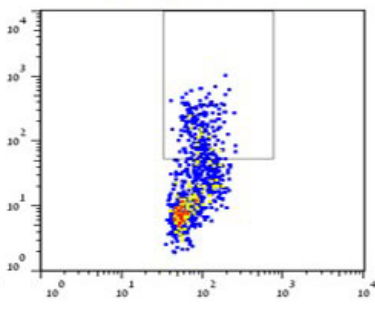

B+A-ATG-60

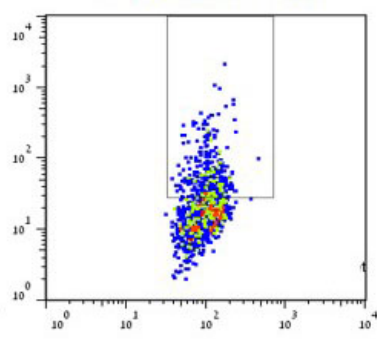

A+A-ATG-120

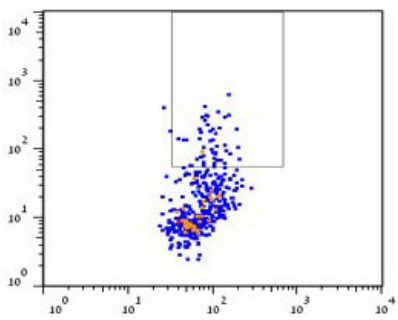

B+A-ATG-120

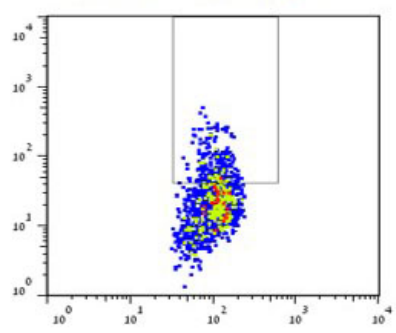

B

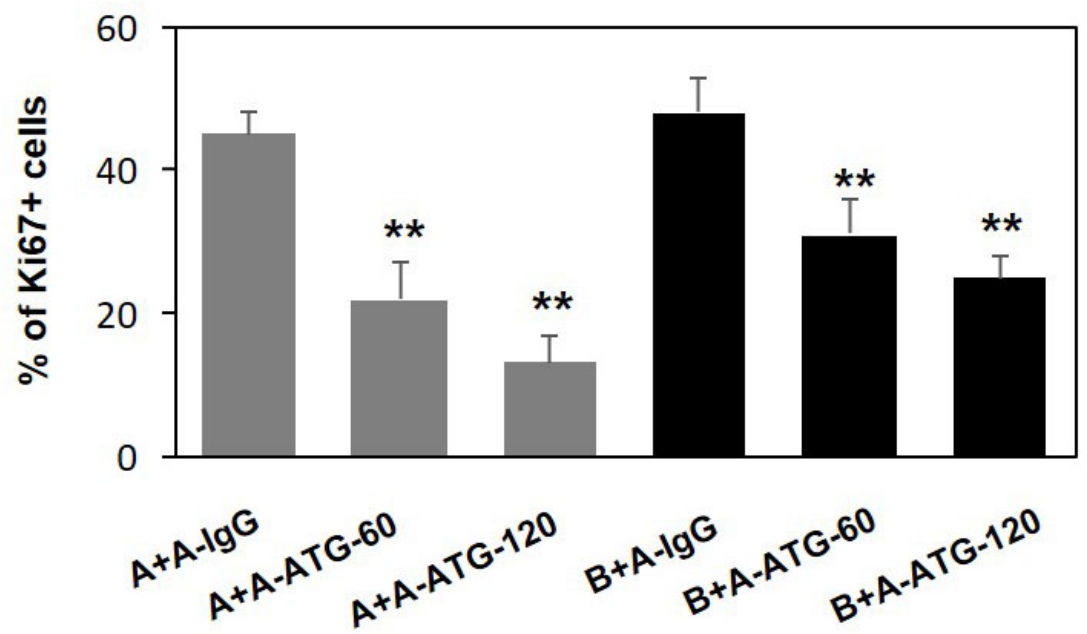

Figure 5: ATG-induced Treg cells are capable to supress both autologus and allogeneic T cell proliferation. PBMCs from donor A were incubated during 48 hours with either IgG or ATG (60 or $120 \mu \mathrm{g} / \mathrm{ml}$ ), and applied to autologous PBMCs (donor A), or to allogeneic PBMCs (Donor B) (at ratio 1:1), stimulated with anti-CD3/anti-CD28 for 5 days. Proliferation was measured by Ki67 expression. A. Representative plots demonstrating Ki67 expression in CD3-poisitve cells. B. Percentage of proliferated CD3+ T cells is presented by the bars as mean of triplicates $\pm \operatorname{STDEV}\left(*^{*} p<0.01\right)$. Data are representative of two independent experiments. 


\section{Sorting of tolerizing population from ATG- induced cells}

Subsequently, in order to enrich the tolerizing population from ATG-treated bulk culture, sorting of CD4+CD25+CD127-low cells (considered as viable regulatory T cells [42]) from ATG-treated PBMCs was performed. Treg phenotyping of the enriched fraction was further confirmed by Foxp3 staining, demonstrating 85\% Foxp3 positive cells in the enriched Treg fraction and only $26 \%$ FoxP 3 -expressing cells in the Treg-negative fraction (Figure 6A). Enriched iTreg+ cells demonstrated a greater suppressive potency than Treg-depleted fraction when added to the autologous stimulated PBMCs (Figure 6B). Of note, Treg-depleted fraction was still able to suppress the proliferation, albeit less efficiently then sorted Treg cells, suggesting that ATG is capable to induce multiple immune suppressive cell populations. Remaining "contaminating" Treg cells may provide another explanation for the suppressive activity of the negative fraction.

A

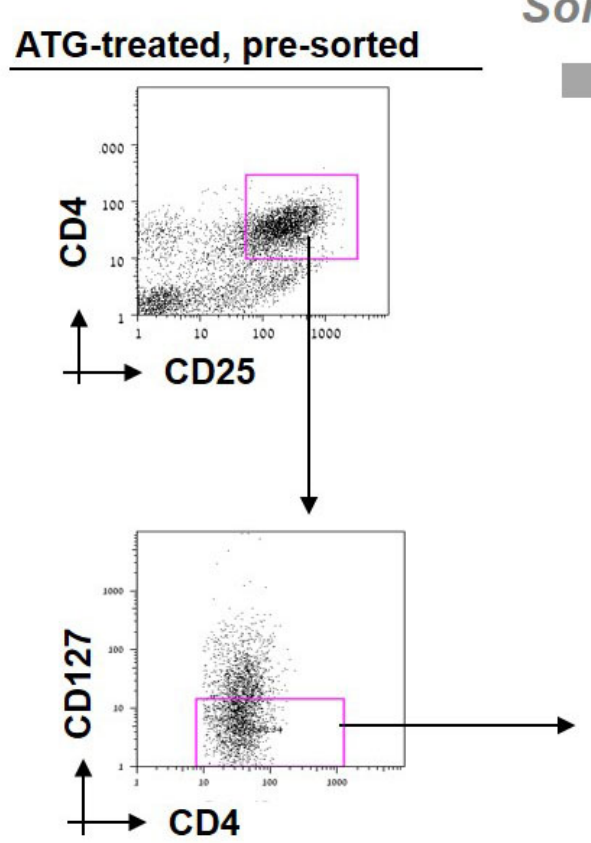

\section{Sorting}

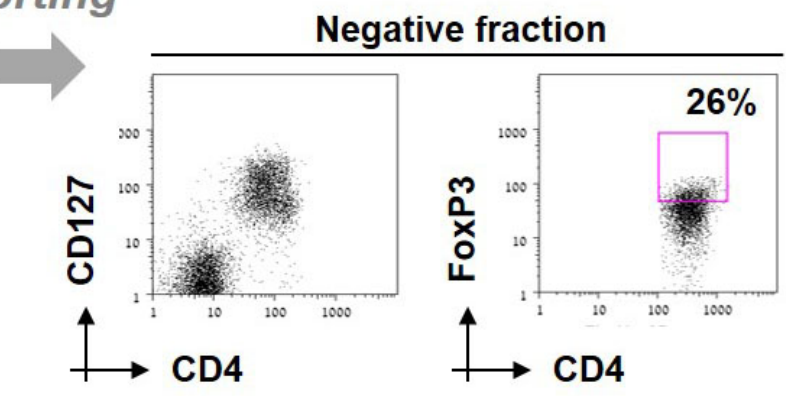

Treg cells (CD4+CD25+CD127-low Foxp3-high)
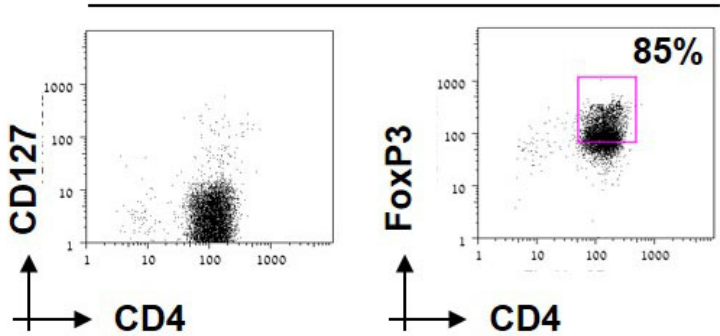

B

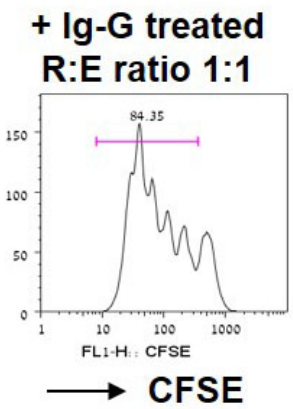

+ Treg sorted $\mathrm{R}:$ : ratio 1:1

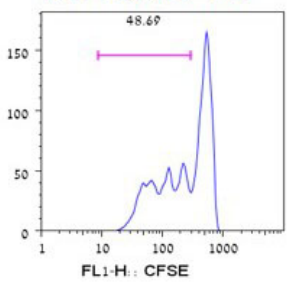

+ Negative fraction $\mathrm{R}: \mathrm{E}$ ratio $1: 1$

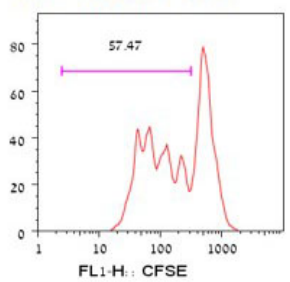

$\%$ of proliferated

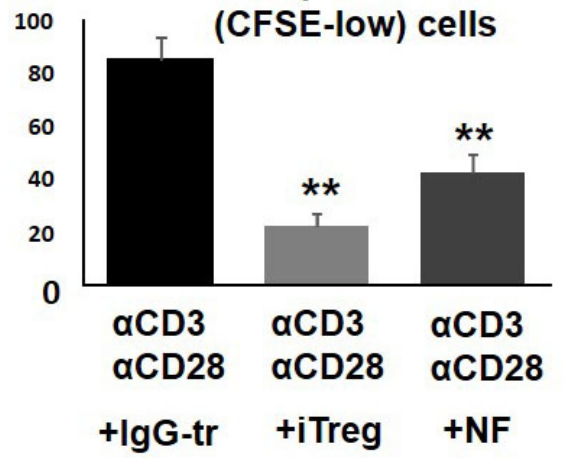

Figure 6: Effect of sorted iTreg cells on T cell proliferation. A. PBMCs were incubated during 48 hours with ATG (60 $\mu \mathrm{g} / \mathrm{ml})$, stained for CD4, CD25 and CD127, and separated into two fractions: CD4+CD25+CD127- cells (enriched with viable Treg cells) and negative fraction. Treg phenotype was confirmed by FoxP3 staining. B. Sorted enriched Treg cells and negative fraction were applied to the stimulated autologous PBMCs and proliferation was measured by CFSE staining. Percentage of proliferated cells is presented by bars as mean of triplicates $\pm \operatorname{STDEV}(* * p<0.01)$. Data are representative of two independent experiments. $\operatorname{Tr}=$ treated. 
Soluble factors secreted by ATG-primed cells are involved in iTreg-mediated tolerance

To explore the possible contribution of soluble factor(s)-mediated mechanisms, in addition to cell to cell contact mechanisms, two approaches were undertaken. First, we examined the suppressive capacity of ATGinduced Treg cells separated from the anti-CD3/anti-
CD28-stimulated CFSE-labeled PBMCs by a permeable membrane. When Treg cells were placed in the top chamber of $0.4 \mu \mathrm{m}$ transwells, their ability to suppress $\mathrm{T}$ cell proliferation located in the lower chamber was impaired, in comparison to the suppressive effect we observed in the direct contact standard co-culture experiments, but it was still significant in comparison to the proliferation with addition of IgG-treated control cells (Figure 7A). Similarly, conditioned medium (CM)

\section{A Proliferation with ATG-iTreg separated by Transwell membrane}

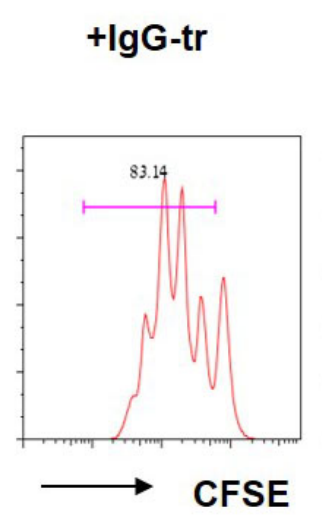

+ATG-iTreg
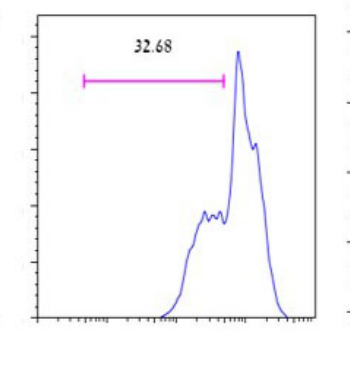

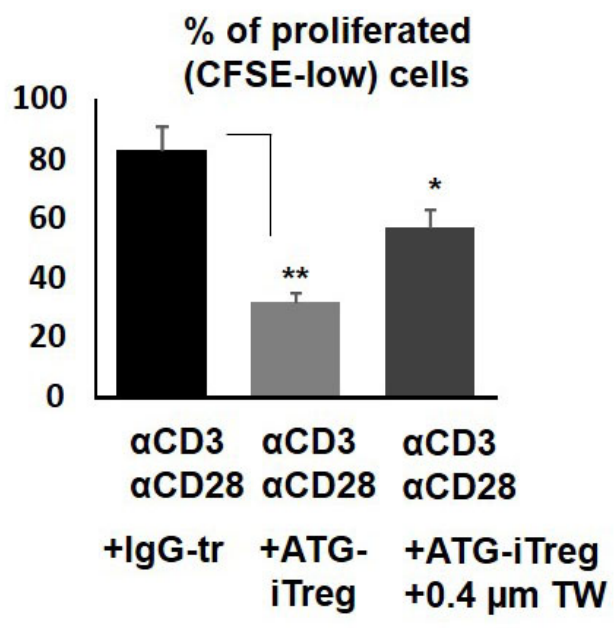

B Proliferation with ATG-iTreg produced conditioned medium
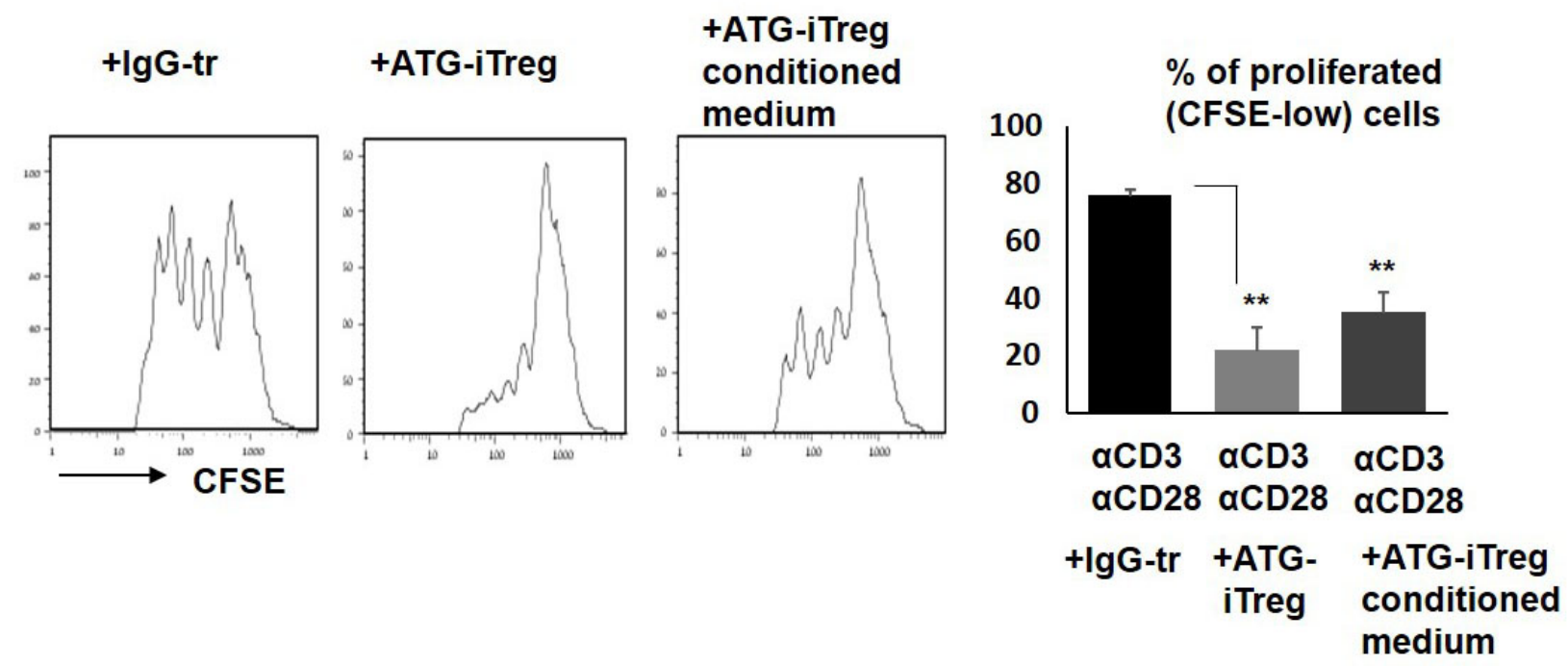

Figure 7: Soluble factors secreted by ATG-primed cells are involved in iTreg-mediated tolerance. Proliferation of autologous PBMCs stimulated with anti-CD3/anti-CD28 antibodies in the presence of A. ATG-primed Treg cells, plated in direct contact or separated with $0.4 \mu \mathrm{m}$ transwells (TW), or B. in the presence of iTreg-produced 50\% conditioned medium. For conditioned medium generation, PBMCs were incubated during 48 hours with ATG $(60 \mu \mathrm{g} / \mathrm{ml})$, ATG was washed out and cell were re-plated in fresh medium for additional 48 hours. Percentage of CFSE-low proliferated cells is presented as mean of triplicates $\pm \operatorname{STDEV}(* * p<0.01)$. Data are representative of two independent experiments. $\mathrm{Tr}=$ treated. 
produced by ATG-primed cells that was added to the stimulated autologous PBMCs was able to significantly suppress their proliferation, albeit less efficiently than direct contact with iTreg cells (Figure 7B). Altogether, these results suggest the presence of soluble factors secreted by ATG-primed cells that are possibly involved in the observed suppression.

\section{TGFß signaling inhibition reverses the suppressive effect of ATG-induced Treg cells}

One of the critical soluble factors known to be produced by Treg cells and being involved in immune suppression is TGF $\beta$ [43]. In order to assess the possible involvement of TGF $\beta$ signaling in the tolerance mediated by ATG-induced Treg cells, secretion of TGF $\beta$ in response to ATG treatment was evaluated. As demonstrated in Figure 8A, a significant dose-dependent increase in TGF $\beta$ levels was detected by ELISA in the culture medium of ATG-treated PBMCs. Next, in order to test the functional role of TGF $\beta$ in our assay and neutralize TGF $\beta$ signaling, we used the selective TGF $\beta$ receptor kinase inhibitor SB431542 [44]. Addition of TGF $\beta R$ inhibitor to the proliferation assay was able to reverse the suppressive effect of Treg cells, thereby increasing the percent of Ki67+ proliferating $\mathrm{T}$ cells. Inhibition of TGF $\beta$ signaling effectively abrogated the suppression promoted by both ATG-induced Treg cells and Treg-produced CM (Figure 8B, 8C). Suppression of IFN $\gamma$ secretion mediated by ATG-induced Treg cells or their CM was reversed upon the addition of SB431542 (Figure 8D). These results indicate the importance of TGF $\beta$ signaling being part of the suppressive mechanism mediated by ATG-primed Treg cells.

\section{TGF $\beta$ signaling and IL-2 signaling are important for ATG-mediated Treg generation}

It is known that TGF $\beta$ not only mediates the suppression promoted by Treg cells, but also induces the acquisition of Foxp3+ Treg phenotype [45, 46]. IL-2 is an additional factor that is important for the generation and survival of Treg cells. Therefore, our next aim was to assess the involvement of TGF $\beta$ and IL-2 signaling in the ATG-promoted acquisition of Treg phenotype. To this end, we added the TGF $\beta$ receptor kinase inhibitor SB431542 and cyclosporine A (CSA) to the Treg generation system, in combination with ATG or control IgG. Treatment with both inhibitors interfered with Treg phenotype acquisition upon ATG induction, and resulted in reduced expression levels of CD25, FoxP3, CD95, PD-1 and GITR markers (Figure 9A). Furthermore, iTregs that were pre-treated with ATG in combination with SB431542 or CSA were not able to suppress the proliferation and IFN $\gamma$ secretion in response to anti-CD3/anti-CD28 stimulation (Figure
9B). These data suggest the pivotal role of the TGF $\beta$ and IL-2 signaling pathways in the acquisition of regulatory phenotype upon ATG treatment.

\section{DISCUSSION}

Since their discovery and based on their properties, Tregs have been an attractive potential cell subset for tolerance induction in different clinical scenarios. In preclinical models of HSCT, Tregs have demonstrated their ability to prevent GVHD while preserving graft versus tumor effects [16, 18, 19, 47, 48]. Different approaches have been attempted for the use of Treg cells in prevention or treatment of acute and chronic GVHD, including the adoptive transfer of Treg cells from different donor sources [22, 49] or enhancement of in vivo Treg function by administration of low doses of IL-2 [50].

The role of ATG in Treg induction has been previously described with recent publications, as well as our own work, indicating that exposure of lymphocytes to ATG not only causes depletion of effector T cells but also induces the preferential expansion of human CD4+CD25+Foxp3+ Tregs in vitro [35-38]. On the other hand, a study by Broady and co-workers did not provide evidence for the existence of thymoglobulin-induced Treg cells but rather related the observed increase in FoxP3 expression to an activated phenotype [39]. Challenging this discriminatory data, here we clearly demonstrate that in vitro treatment of PBMCs with ATG-F is capable of increasing the frequency of functional Treg cells, which are able to suppress the proliferation and activation of autologous and allogeneic stimulated T cells.

Importantly, we found that ATG treatment significantly increases the surface expression of complement regulatory molecules CD55, CD58 and CD59 on the generated Treg cells. Previous works show that in contrast to effector T cells, complement components rather activate and expand Treg cells [51]. CD55 was identified as co-stimulator and activator of human naive CD4+ cells, resulting in the differentiation of a discrete Treg population [52]. CD58 co-stimulation (together with was CD2) was found to be important for Treg function [53]. Therefore, the observed up-regulation of CD55, CD58 and CD59 expression on ATG-induced Treg cells potentially can lead to increased resistance of Treg to complement-mediated lysis, and conversely to increased FoxP3 expression and Treg function.

Little is known about the mechanisms underlying the effects promoted by ATG to induce Treg as well as the mechanism underlying tolerogenic activity of these cells. Therefore, our work was directed to decipher the mechanism of action of ATG-induced Treg cells. Several mechanisms have been proposed for the observed Treg-induced tolerance and the suppressive mediators. Production of suppressive cytokines, including IL-10 and TGF $\beta$ have been shown to be important in Treg- 

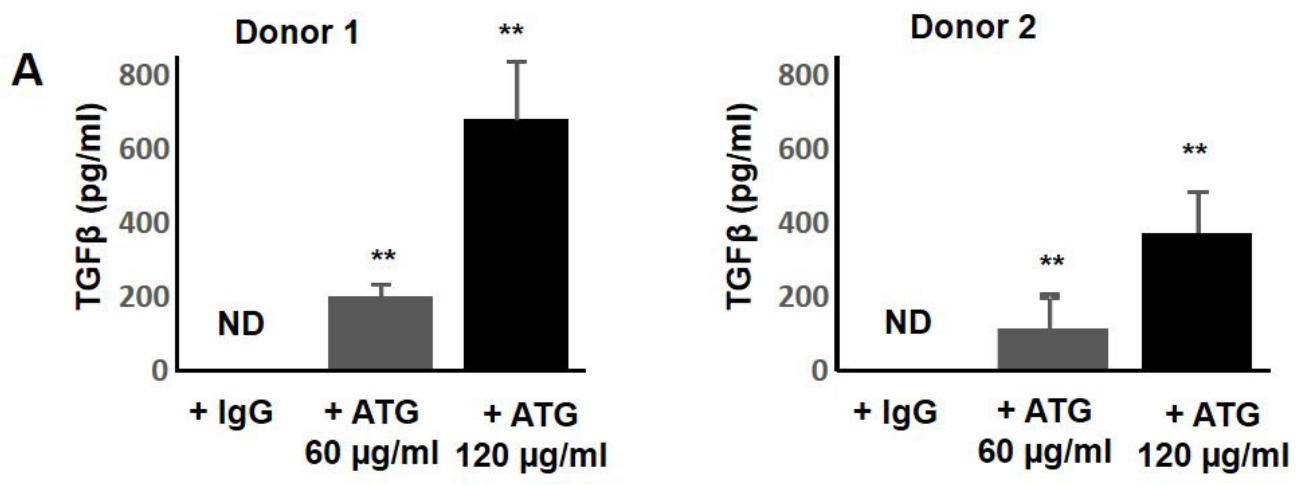

B

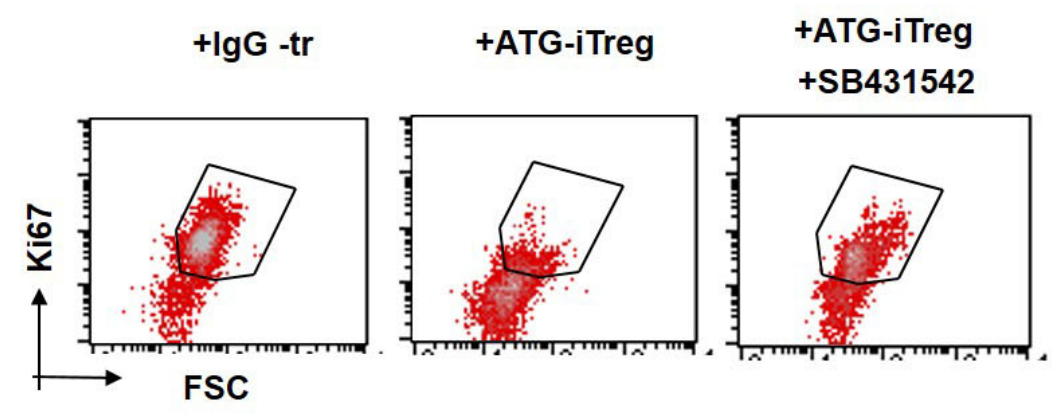

C
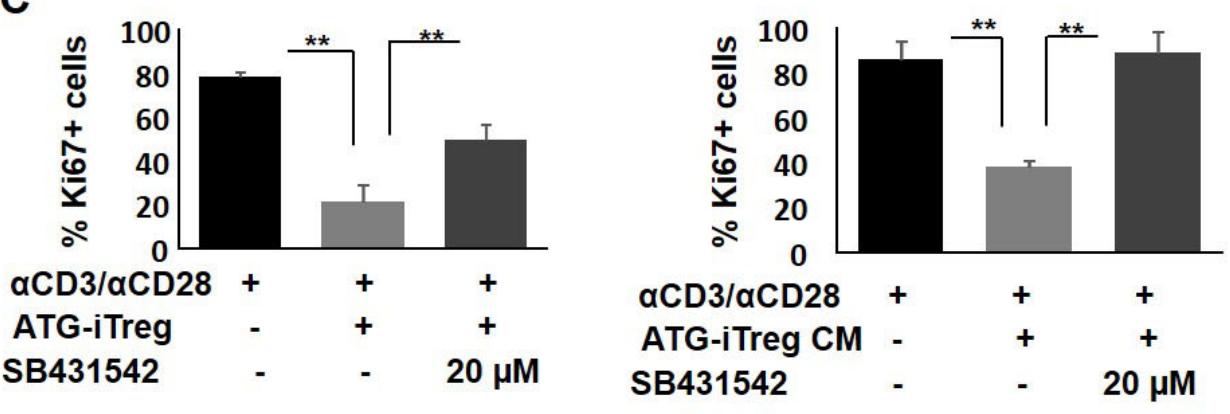

D
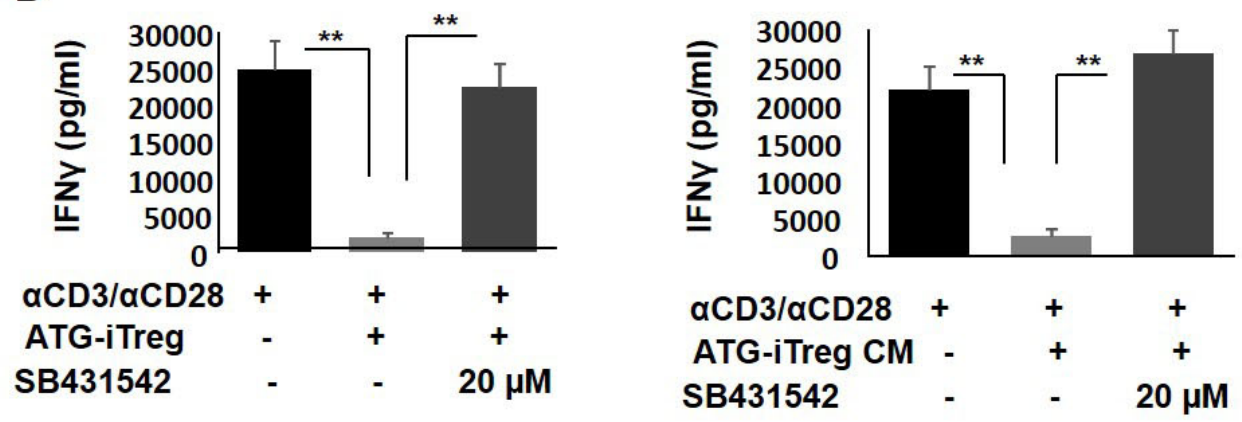

Figure 8: The role of TGF $\beta$ in ATG-related Treg induction and their suppressive capacity. A. TGF $\beta$ secretion from ATG -treated PBMCs. PBMCs were treated during 48 hours with indicated concentration of ATG and TGF $\beta$ was assessed using ELISA method. B.-C. Proliferation of PBMCs in response to anti-CD3/anti-CD28 stimulation, in the absence or presence of autologous ATG-primed iTreg cells or addition of $50 \%$ conditioned medium (CM) produced by ATG-pretreated iTreg cells in the absence or presence of TGF $\beta$ receptor kinase inhibitor SB431542 $(10$ or $20 \mu \mathrm{M})$, during 5 days of culture. (B) Representative flow cytometry plots demonstrating Ki67 expression. (C) Percentage of proliferated Ki67-poistive cells is presented by bars as mean of triplicates $\pm \mathrm{STDEV}(* * p<0.01)$. D. Activation measured by IFN $\gamma$ levels secreted in the absence or presence of TGF $\beta$ receptor kinase inhibitor SB431542, using ELISA. Data is presented as mean of triplicates $\pm \mathrm{STDEV},{ }^{*} p<0.01$. Data are representative of three independent experiments. 

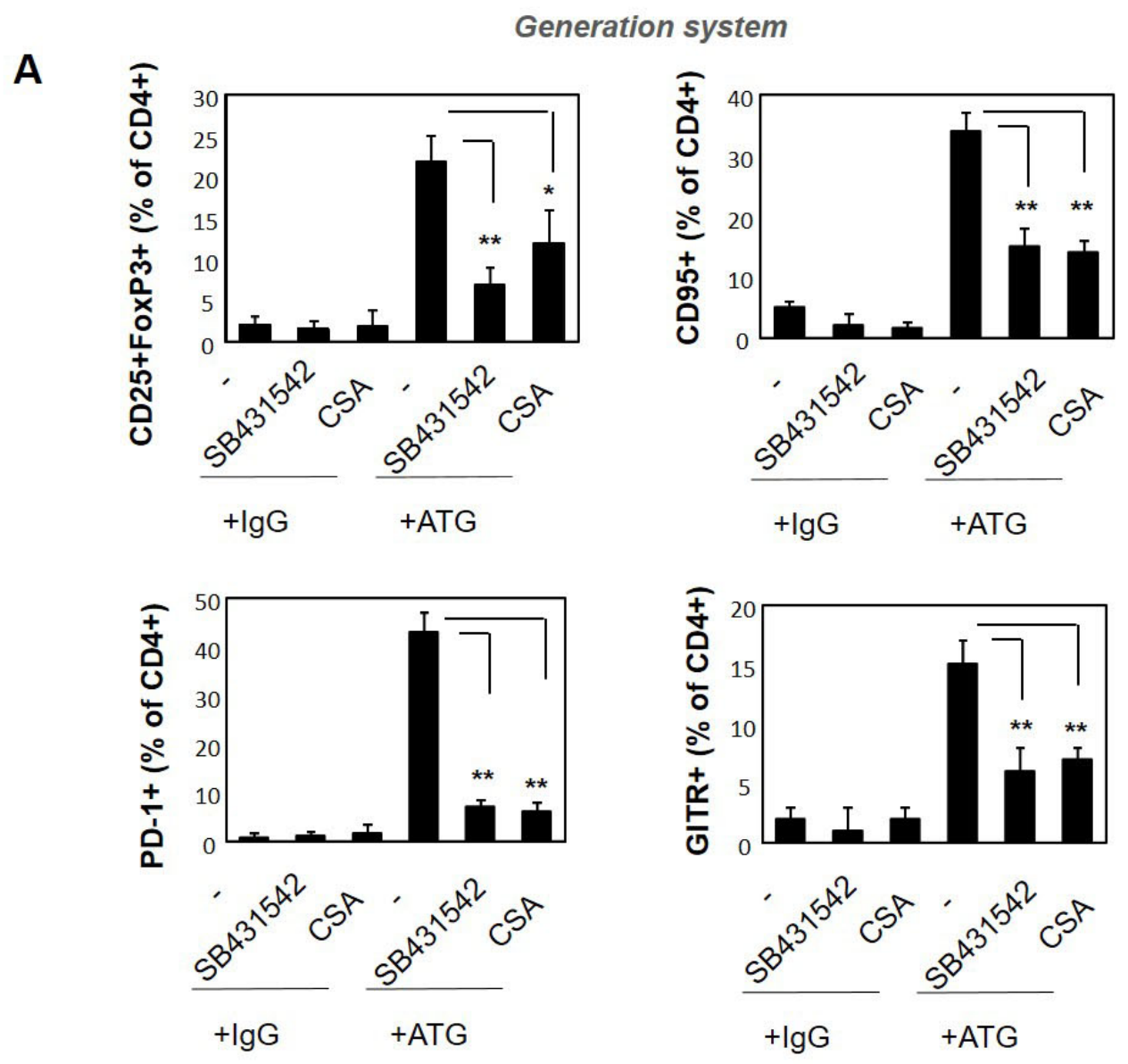

B

Indication system
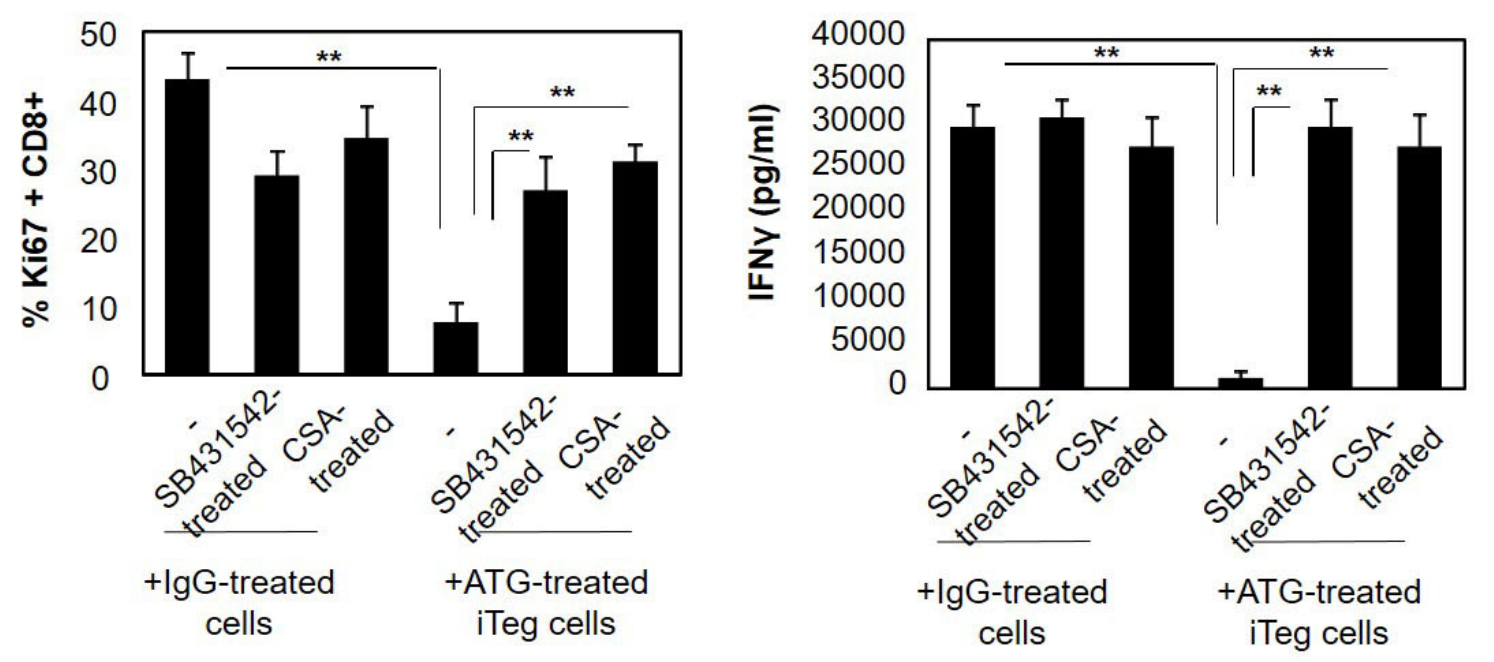

Figure 9: Pre-treatment with SB431542 or CSA interferes with ATG-mediated Treg induction. PBMCs were incubated during 48 hours with either IgG or ATG $(60 \mu \mathrm{g} / \mathrm{ml})$, in the absence or presence of SB431542 $(20 \mu \mathrm{M})$ or CSA $(1 \mu \mathrm{g} / \mathrm{ml})$. A. Expression of Treg markers was evaluated by flow cytometry. Percentage of CD4+ cells expressing CD25+/Foxp3, CD95, PD-1 and GITR are presented as mean of triplicates $\pm \mathrm{STDEV}, * * p<0.01$. B. ATG-induced Treg cells, cultured in the absence or presence of SB431542 or CSA were applied on autologous PBMCs (1:1 ratio) and stimulated with anti-CD3/anti-CD28 for five days. Proliferation and activation were assessed by Ki67 staining and IFN $\gamma$ secretion measurement, respectively. Percentage of proliferated Ki67-poistive cells is presented as mean of triplicates $\pm \operatorname{STDEV}(* * p<0.01)$. Data are representative of three independent experiments. 
mediated suppression [54, 55]. Treg function can be also mediated by cell to cell contacts, utilizing contactdependent molecules, such as CTLA-4, granzymes and perforins [56, 57]. However, the mechanism by which ATG-induced Treg cells promote tolerance and suppress effector $\mathrm{T}$ cell activation and proliferation has not been fully elucidated yet. Here we demonstrate the importance of TGF $\beta$ signaling in both phases: the initial Treg phenotype acquisition promoted by ATG and the subsequent suppression mediated by induced Treg cells were both interfered upon TGF $\beta$ inhibition. TGF $\beta$ blockade with a specific TGF $\beta$ receptor kinase inhibitor was able to prevent the effect of ATG and resulted in reduced expression of Treg markers in ATG-treated cells. Similarly, inhibition of TGF $\beta$ with SB431542 impaired the immune suppression promoted by ATG-induced Treg cells and reversed the proliferation and activation of autologous $\mathrm{T}$ cells in response to anti-CD3/CD28 stimulation. Previous studies that assessed the possible involvement of TGF $\beta$ in ATG-related Treg expansion demonstrated some controversy regarding the role of TGF $\beta$. In one study using thymoglobulin no TGF $\beta$ gene expression was observed in PBMCs upon treatment with theanti-thymocyte globulin [58]. Another study evaluated the effect of thymoglobulin on cytokine secretion in ex vivo treated $\mathrm{T}$ cells, and detected mainly IL-10 increase without TGF $\beta$ secretion in response to the treatment [59]. In contrast, increase in TGF $\beta$ expression following ATG treatment was reported in several other studies. For instance, clinical study in renal allograft recipients treated with ATG-F demonstrated increase in TGF $\beta$ gene expression in PBMCs [60]. Different sources of ATG and different experimental protocols may explain the discrepancies. Nevertheless, our findings support the importance of TGF $\beta$ pathway in ATGmediated tolerance and suggest its possible involvement in clinical settings of allogeneic HSCT. Complementing the results of previous studies we now show the mechanistical link between ATG-induced Treg generation, the release of TGF $\beta$ and its immunosuppressive activity.

ATG is polyclonal and can recognize multiple antigens and affect different cell populations. Identification and isolation of specific defined and potent immunosuppressive populations is important step toward better understanding of ATG-related properties and efficacious application in the clinical settings. We show here that viable CD4+CD25+CD127-low Treg cells isolated from bulk culture of ATG-treated PBMCs demonstrate preferential suppressive activity comparing to non-sorted population. However, it was interesting to learn that residual negative fraction of ATG-treated cells is also able to suppress the proliferation of autologous cells, albeit less efficient than purified Treg cells. These results suggest that in addition to Treg cells, ATG may have an impact on other suppressive populations. Indeed, it was demonstrated that ATG-mediated Treg expansion requires the presence of monocytes in culture, and generation of tolerogenic
CD14+CD11c+ dendritic cells was detected upon ATG treatment [58]. The role of dendritic cells in the induction of lymphocyte tolerance is established phenomenon [61]. However, the role of ATG and its effects on different immune cell populations, including tolerogenic myeloid cells, should be further characterized and possibly utilized in anti-GVHD therapeutics development.

Numerous factors may affect a given patient's response to ATG treatment. The type of the pretransplantation conditioning, the type of GHVD prophylaxis, the number and type of immune cells in the patient's peripheral blood and the immune cell composition of the graft - all these factors may significantly impact the ATG-mediated effects and clinical responses and future research needs to address these issues.

Among immunosuppressive agents, it was shown that CSA has a negative impact on Treg cells, impairing their inhibitory activity $[36,62]$. CSA, which disturbs IL-2 signaling, but not rapamycin, has been shown to suppress the ability of Treg cells to inhibit the proliferation of stimulated PBMCs [63]. Consistently, in our experiments, the combination of ATG with CSA was found to be unfavorable for Treg induction. To this end, CSA treatment interfered with ATG-promoted effects, significantly reducing the induction of Treg markers upon ATG treatment, and suppressing the inhibitory activity Treg cells.

Recent work had demonstrated the importance of ATG binding to immune cell populations following allogeneic HSCT. It has been shown that high levels of ATG antibodies bound to T and B cells on day 7 posttransplantation are associated with a low risk of aGVHD [64]. Among all immune cells, ATG has the highest affinity for naïve $T$ cells [65], which are enriched for alloreactive $\mathrm{T}$ cells [66]. However, in addition to depletion of effector $T$ cells transferred with graft, ATG binding may result in Treg induction, possibly affecting either donor as well as recipient $\mathrm{T}$ cells. Our recent in vitro results demonstrate the suppressive potential of ATG-generated Treg against either autologous or allogeneic cells. We suggest that ATG-induced regulatory $T$ cells of both patient and graft origin may suppress the activation and proliferation of alloreactive donor T cells, although we do not have yet formal prove for this. Another question to be explored is the influence of Treg in general and ATG-induced Treg, more specifically, on graft versus tumor (GVT) effect.

Altogether, we demonstrate here that ex vivo treatment with ATG potently induces expansion of functional Treg cells which are able to suppress the proliferation and activation of both autologous and allogeneic effector T cells. We found that ATG-mediated Treg induction and activity was partially dependent on TGF $\beta$ signaling. Therefore, the therapeutic effects of ATG in the settings of allogeneic HSCT may be the result of not only lymphocyte depletion but also enhanced Treg cell number and function, and may be important for GVHD 
prevention and efficient engraftment.

Further insight into the basic biology of Treg cells will aid in translating preclinical data for the benefit of patients.

\section{MATERIALS AND METHODS}

\section{Immunosuppressive drugs and control antibodies}

Following drugs and inhibitors were used in the study: rATG (Neovii-Biotech), a purified IgG fraction derived from rabbits immunized with Jurkat $\mathrm{T}$ cell line. Control rabbit IgG purified from whole normal rabbit serum was used (Sigma-Aldrich, Israel). Cyclosporine A was purchased from Sigma-Aldrich, SB431542 from Cayman.

\section{Cell isolation and induction culture}

Heparinized blood samples from healthy volunteers were collected after written informed consent. The the study was approved by the institutional review board and Israeli Ministry of Health. Peripheral blood mononuclear cells (PBMCs) were isolated by standard Ficoll density gradient centrifugation. For Treg induction, PBMCs $\left(10^{6} / \mathrm{mL}\right)$ were incubated with $\mathrm{rATG}$, or $\mathrm{rgG}$, (each at $60 \mu \mathrm{g} / \mathrm{mL}$ or $120 \mu \mathrm{g} / \mathrm{mL}$ ), in the presence or absence of CSA $(1.0 \mu \mathrm{g} / \mathrm{mL})$ or SB431542 in RPMI 1640 medium supplemented with $10 \%$ heat-inactivated fetal calf serum at $37^{\circ} \mathrm{C}, 95 \%$ humidity, and $5 \% \mathrm{CO}_{2}$ for 48 hours. Supernatants were collected for cytokine detection. Cells were collected for flow cytometry analysis or functional assays.

\section{Flow cytometry analysis}

Expression of markers associated with Treg phenotype was evaluated by flow cytometry. Briefly, PBMCs were first stained with antihuman CD4fluorescein isothiocyanate (FITC) and CD25phycoerythrin (PE) (eBioscience, San Diego, CA). As a next step, intracellular staining for FOXP3 detection was performed using antihuman FOXP3-allophycocyanin (APC; PCH101FOXP3) commercial kit according to manufacturer's instructions (eBioscience). Additional markers were analyzed, including CD3-FITC, CD8PE-CY7, CD69-PE, CD95-FITC, GITR-PE, ICOS-PECY7, PD-1-FITC, CD55-APC, CD58-APC, CD59-APC (purchased from eBioscience, Biolegnd or TONBO). Finally, cells were analyzed on the FACSCalibur (Becton Dickinson) using the CellQuest software (BD Biosciences) and FlowJo software.

\section{Isolation of viable Treg cells}

Following the induction treatment with ATG, cells were co-stained with anti-CD4-FITC, antiCD25-PE and anti-CD127-APC and sterile sorting of CD4+CD25+CD127-low cell population (considered as positive fraction enriched with viable Treg cells, [42] versus mixed population of $\mathrm{CD} 4+\mathrm{CD} 127$-high cells together with CD4-negative cells (considered as negative fraction) was performed using FACSAria II cell sorter (Becton Dickinson). Cell purity was confirmed using subsequent Foxp3 of sorted cell populations. Sorted cells were proceeded for functional assays.

\section{Proliferation assays}

To assess the suppressive capacity of unsorted and sorted ATG-induced Treg cells, the cells were co-cultured with autologous or allogeneic PBMCs (responders) at 1:1 ratio in the presence of $1 \mu \mathrm{g} / \mathrm{mL}$ soluble anti-CD3 (OKT3, eBioscience) and $1 \mu \mathrm{g} / \mathrm{mL}$ soluble anti-CD28 (CD28.2, eBioscience). After culture for five days, proliferation was evaluated using Carboxyfluorescein diacetate succinimidyl ester (CFSE) dilution method or by Ki67 intra-cellular staining. For CFSE staining, prior to the incubation cells were labeled with $5 \mu \mathrm{M}$ CFSE (eBioscience) according to manufacturer's instructions and analyzed five days later by flow cytometry for the loss of fluorescence. For Ki67 detection, cells were harvested following the proliferation and subjected to intra-cellular staining using FOXP3 fixation and permeabilization buffers kit (eBioscience) and anti-Ki67-APC conjugated antibody (eBioscience).

\section{Conditioned medium generation and experiments with transwells}

To evaluate the effect of secreted factors produced by iTreg cells, conditioned medium (CM) was generated. PBMCs $\left(10^{6} / \mathrm{mL}\right)$ were pre-treated with either $\operatorname{IgG}$ or ATG for 48 hours, washed three times with PBSx1 and re-plated in fresh medium for additional 48 hours. Culture supernatants were isolated by centrifugation to remove cellular contamination prior to use in assays. Transwell experiments were performed using $0.4 \mu \mathrm{m}$ pore size Transwell $^{\mathrm{TM}}$ system (Corning, Costar). Responder PBMCs were plated in the down chamber, IgG- or ATG-pretreated iTreg cells were placed in the upper chamber. Cells were stimulated with anti-CD3/anti-CD28 for 5 days and proliferation was assessed as described above.

\section{Enzyme-linked immunosorbent assay (ELISA)}

The levels of INF $\gamma$ or TGF $\beta$ in the supernatants of treated cells were measured using commercially available 
ELISA kits according to the manufacturer's instructions (eBioscience). Samples and standards were tested in triplicates.

\section{Statistical analyses}

Data are expressed as the mean \pm standard deviation (STDEV). Statistical comparisons of means were performed by a two-tailed unpaired Student's $t$ test.

\section{Authorship}

K.B., D.N. and A.N. conceived and designed the experiments; K.B., V.V., O.O., H.B., V.M. and E.R. performed the experiments; K.B., D.N. and A.N. analyzed the data; N.B., I.D., A.S. and A.N. contributed with samples and materials; and K.B., D.N., J.C. and A.N. wrote the paper.

\section{CONFLICTS OF INTERESTS}

The authors declare no competing financial interests.

\section{FUNDING}

Research grant to A.N. from Neovii-Biotech.

\section{REFERENCES}

1. Hart DP, Peggs KS. Current status of allogeneic stem cell transplantation for treatment of hematologic malignancies. Clin Pharmacol Ther. 2007; 82:325-329.

2. Alyea E, Weller E, Schlossman R, Canning C, Mauch P, Ng A, Fisher D, Gribben J, Freeman A, Parikh B, Richardson P, Soiffer R, Ritz J, et al. Outcome after autologous and allogeneic stem cell transplantation for patients with multiple myeloma: impact of graft-versus-myeloma effect. Bone Marrow Transplant. 2003; 32:1145-1151.

3. Goldstone AH, Richards SM, Lazarus HM, Tallman MS, Buck G, Fielding AK, Burnett AK, Chopra R, Wiernik PH, Foroni L, Paietta E, Litzow MR, Marks DI, et al. In adults with standard-risk acute lymphoblastic leukemia, the greatest benefit is achieved from a matched sibling allogeneic transplantation in first complete remission, and an autologous transplantation is less effective than conventional consolidation/maintenance chemotherapy in all patients: final results of the International ALL Trial (MRC UKALL XII/ECOG E2993). Blood. 2008; 111:18271833.

4. Koreth J, Schlenk R, Kopecky KJ, Honda S, Sierra J, Djulbegovic BJ, Wadleigh M, DeAngelo DJ, Stone RM, Sakamaki H, Appelbaum FR, Dohner H, Antin JH, et al. Allogeneic stem cell transplantation for acute myeloid leukemia in first complete remission: systematic review and meta-analysis of prospective clinical trials. JAMA. 2009; 301:2349-2361.

5. Zuckerman T, Rowe JM. Hematopoietic stem cell transplantation for adults with acute lymphoblastic leukemia. Curr Opin Hematol. 2009; 16:453-459.

6. Ruggeri L, Mancusi A, Capanni M, Urbani E, Carotti A, Aloisi T, Stern M, Pende D, Perruccio K, Burchielli E, Topini F, Bianchi E, Aversa F, et al. Donor natural killer cell allorecognition of missing self in haploidentical hematopoietic transplantation for acute myeloid leukemia: challenging its predictive value. Blood. 2007; 110:433-440.

7. Pollack SM, O'Connor TP Jr, Hashash J, Tabbara IA. Nonmyeloablative and reduced-intensity conditioning for allogeneic hematopoietic stem cell transplantation: a clinical review. Am J Clin Oncol. 2009; 32:618-28.

8. Jenq RR, van den Brink MR. Allogeneic haematopoietic stem cell transplantation: individualized stem cell and immune therapy of cancer. Nat Rev Cancer. 2010; 10:213221.

9. Choi SW, Levine JE, Ferrara JL. Pathogenesis and management of graft-versus-host disease. Immunol Allergy Clin North Am. 2010; 30:75-101.

10. Ferrara JL, Levine JE, Reddy P, Holler E. Graft-versus-host disease. Lancet. 2009; 373:1550-1561.

11. Boeckh M, Erard V, Zerr D, Englund J. Emerging viral infections after hematopoietic cell transplantation. Pediatr Transplant. 2005 (Suppl 7); 9:48-54.

12. Bunjes D. The current status of T-cell depleted allogeneic stem-cell transplants in adult patients with AML. Cytotherapy. 2001; 3:175-188.

13. Kolb HJ. Graft-versus-leukemia effects of transplantation and donor lymphocytes. Blood. 2008; 112:4371-4383.

14. Sakaguchi S, Powrie F, Ransohoff RM. Re-establishing immunological self-tolerance in autoimmune disease. Nat Med. 2012; 18:54-58.

15. Josefowicz SZ, Lu LF, Rudensky AY. Regulatory T cells: mechanisms of differentiation and function. Annu Rev Immunol. 2012; 30:531-564.

16. Cohen JL, Trenado A, Vasey D, Klatzmann D, Salomon BL. CD4(+)CD25(+) immunoregulatory T Cells: new therapeutics for graft-versus-host disease. J Exp Med. 2002; 196:401-406.

17. Taylor PA, Lees CJ, Blazar BR. The infusion of ex vivo activated and expanded CD4(+)CD25(+) immune regulatory cells inhibits graft-versus-host disease lethality. Blood. 2002; 99:3493-3499.

18. Hoffmann P, Ermann J, Edinger M, Fathman CG, Strober S. Donor-type CD4(+)CD25(+) regulatory T cells suppress lethal acute graft-versus-host disease after allogeneic bone marrow transplantation. J Exp Med. 2002; 196:389-399.

19. Zorn E, Kim HT, Lee SJ, Floyd BH, Litsa D, Arumugarajah S, Bellucci R, Alyea EP, Antin JH, Soiffer RJ, Ritz J. Reduced frequency of FOXP3+ CD4+CD25+ regulatory $\mathrm{T}$ cells in patients with chronic graft-versus-host disease. 
Blood. 2005; 106:2903-2911.

20. Rieger K, Loddenkemper C, Maul J, Fietz T, Wolff D, Terpe H, Steiner B, Berg E, Miehlke S, Bornhauser M, Schneider T, Zeitz M, Stein H, et al. Mucosal FOXP3+ regulatory $\mathrm{T}$ cells are numerically deficient in acute and chronic GvHD. Blood. 2006; 107:1717-1723.

21. Riley JL, June CH, Blazar BR. Human T regulatory cell therapy: take a billion or so and call me in the morning. Immunity. 2009; 30:656-665.

22. Brunstein CG, Miller JS, Cao Q, McKenna DH, Hippen KL, Curtsinger J, Defor T, Levine BL, June CH, Rubinstein P, McGlave PB, Blazar BR, Wagner JE. Infusion of ex vivo expanded $\mathrm{T}$ regulatory cells in adults transplanted with umbilical cord blood: safety profile and detection kinetics. Blood. 2011; 117:1061-1070.

23. Di Ianni M, Falzetti F, Carotti A, Terenzi A, Castellino F, Bonifacio E, Del Papa B, Zei T, Ostini RI, Cecchini D, Aloisi T, Perruccio K, Ruggeri L, et al. Tregs prevent GVHD and promote immune reconstitution in HLAhaploidentical transplantation. Blood. 2011; 117:39213928.

24. Storek J, Mohty M, Boelens JJ. Rabbit anti-T cell globulin in allogeneic hematopoietic cell transplantation. Biol Blood Marrow Transplant. 2015; 21:959-970.

25. Kohrt HE, Turnbull BB, Heydari K, Shizuru JA, Laport GG, Miklos DB, Johnston LJ, Arai S, Weng WK, Hoppe RT, Lavori PW, Blume KG, Negrin RS, et al. TLI and ATG conditioning with low risk of graft-versus-host disease retains antitumor reactions after allogeneic hematopoietic cell transplantation from related and unrelated donors. Blood. 2009; 114:1099-1109.

26. Marks DI, Lush R, Cavenagh J, Milligan DW, Schey S, Parker A, Clark FJ, Hunt L, Yin J, Fuller S, Vandenberghe E, Marsh J, Littlewood T, et al. The toxicity and efficacy of donor lymphocyte infusions given after reduced-intensity conditioning allogeneic stem cell transplantation. Blood. 2002; 100:3108-3114.

27. Devillier R, Furst S, El-Cheikh J, Castagna L, Harbi S, Granata A, Crocchiolo R, Oudin C, Mohty B, Bouabdallah R, Chabannon C, Stoppa AM, Charbonnier A, et al. Antithymocyte globulin in reduced-intensity conditioning regimen allows a high disease-free survival exempt of longterm chronic graft-versus-host disease. Biol Blood Marrow Transplant. 2014; 20:370-374.

28. Finke J, Bethge WA, Schmoor C, Ottinger HD, Stelljes M, Zander AR, Volin L, Ruutu T, Heim DA, Schwerdtfeger R, Kolbe K, Mayer J, Maertens JA, et al, and ATG-Fresenius Trial Group. Standard graft-versus-host disease prophylaxis with or without anti-T-cell globulin in haematopoietic cell transplantation from matched unrelated donors: a randomised, open-label, multicentre phase 3 trial. Lancet Oncol. 2009; 10:855-64.

29. Socié G, Schmoor C, Bethge WA, Ottinger HD, Stelljes M, Zander AR, Volin L, Ruutu T, Heim DA, Schwerdtfeger R, Kolbe K, Mayer J, Maertens JA, et al, and ATG-Fresenius
Trial Group. Chronic graft-versus-host disease: long-term results from a randomized trial on graft-versus-host disease prophylaxis with or without anti-T-cell globulin ATGFresenius. Blood. 2011; 117:6375-6382.

30. Soiffer RJ, Lerademacher J, Ho V, Kan F, Artz A, Champlin RE, Devine S, Isola L, Lazarus HM, Marks DI, Porter DL, Waller EK, Horowitz MM, Eapen M. Impact of immune modulation with anti-T-cell antibodies on the outcome of reduced-intensity allogeneic hematopoietic stem cell transplantation for hematologic malignancies. Blood. 2011; 117:6963-6970.

31. Kroger N, Solano C, Wolschke C, Bandini G, Patriarca F, Pini M, Nagler A, Selleri C, Risitano A, Messina G, Bethge W, Perez de Oteiza J, Duarte R, et al. Antilymphocyte Globulin for Prevention of Chronic Graft-versus-Host Disease. N Engl J Med. 2016; 374:43-53.

32. Servais S, Menten-Dedoyart C, Beguin Y, Seidel L, Gothot A, Daulne C, Willems E, Delens L, Humblet-Baron S, Hannon M, Baron F. Impact of Pre-Transplant Anti-T Cell Globulin (ATG) on Immune Recovery after Myeloablative Allogeneic Peripheral Blood Stem Cell Transplantation. PLoS One. 2015; 10:e130026.

33. Hannon M, Lechanteur C, Lucas S, Somja J, Seidel L, Belle L, Bruck F, Baudoux E, Giet O, Chantillon AM, Delvenne $\mathrm{P}$, Drion $\mathrm{P}$, Beguin $\mathrm{Y}$, et al. Infusion of clinical-grade enriched regulatory $\mathrm{T}$ cells delays experimental xenogeneic graft-versus-host disease. Transfusion. 2014; 54:353-363.

34. Matsuoka K, Koreth J, Kim HT, Bascug G, McDonough S, Kawano Y, Murase K, Cutler C, Ho VT, Alyea EP, Armand $\mathrm{P}$, Blazar BR, Antin JH, et al. Low-dose interleukin-2 therapy restores regulatory $\mathrm{T}$ cell homeostasis in patients with chronic graft-versus-host disease. Sci Transl Med. 2013; 5:179ra143.

35. Lopez M, Clarkson MR, Albin M, Sayegh MH, Najafian N. A novel mechanism of action for anti-thymocyte globulin: induction of CD4+CD25+Foxp3+ regulatory T cells. J Am Soc Nephrol. 2006; 17:2844-2853.

36. Feng X, Kajigaya S, Solomou EE, Keyvanfar K, Xu X, Raghavachari N, Munson PJ, Herndon TM, Chen J, Young NS. Rabbit ATG but not horse ATG promotes expansion of functional CD4+CD25highFOXP3+ regulatory T cells in vitro. Blood. 2008; 111:3675-3683.

37. Ruzek MC, Waire JS, Hopkins D, Lacorcia G, Sullivan J, Roberts BL, Richards SM, Nahill SR, Williams JM, Scaria A, Dzuris J, Shankara S, Garman RD. Characterization of in vitro antimurine thymocyte globulin-induced regulatory $\mathrm{T}$ cells that inhibit graft-versus-host disease in vivo. Blood. 2008; 111:1726-1734.

38. Shimony O, Nagler A, Gellman YN, Refaeli E, Rosenblum N, Eshkar-Sebban L, Yerushalmi R, Shimoni A, Lytton SD, Stanevsky A, Or R, Naor D. Anti-T lymphocyte globulin (ATG) induces generation of regulatory T cells, at least part of them express activated CD44. J Clin Immunol. 2012; 32:173-188.

39. Broady R, Yu J, Levings MK. ATG-induced expression 
of FOXP3 in human CD4(+) T cells in vitro is associated with T-cell activation and not the induction of FOXP3 $(+) \mathrm{T}$ regulatory cells. Blood. 2009; 114:5003-5006.

40. Baron F, Mohty M, Blaise D, Socie G, Labopin M, Esteve J, Ciceri F, Giebel S, Gorin NC, Savani BN, Schmid C, Nagler A. Anti-thymocyte globulin as graft-versus-host disease prevention in the setting of allogeneic peripheral blood stem cell transplantation: a review from the Acute Leukemia Working Party of the European Society for Blood and Marrow Transplantation. Haematologica. 2017; 102:224-234.

41. Bunn D, Lea CK, Bevan DJ, Higgins RM, Hendry BM. The pharmacokinetics of anti-thymocyte globulin (ATG) following intravenous infusion in man. Clin Nephrol. 1996; 45:29-32.

42. Liu W, Putnam AL, Xu-Yu Z, Szot GL, Lee MR, Zhu S, Gottlieb PA, Kapranov P, Gingeras TR, Fazekas de St Groth B, Clayberger C, Soper DM, Ziegler SF, Bluestone JA. CD127 expression inversely correlates with FoxP3 and suppressive function of human CD4+ T reg cells. J Exp Med. 2006; 203:1701-11.

43. Li MO, Wan YY, Flavell RA. T cell-produced transforming growth factor-betal controls $\mathrm{T}$ cell tolerance and regulates Th1- and Th17-cell differentiation. Immunity. 2007; 26:579-591.

44. Inman GJ, Nicolas FJ, Callahan JF, Harling JD, Gaster LM, Reith AD, Laping NJ, Hill CS. SB-431542 is a potent and specific inhibitor of transforming growth factor-beta superfamily type I activin receptor-like kinase (ALK) receptors ALK4, ALK5, and ALK7. Mol Pharmacol. 2002; 62:65-74.

45. Chen W, Jin W, Hardegen N, Lei KJ, Li L, Marinos N, McGrady G, Wahl SM. Conversion of peripheral CD4+CD25- naive $\mathrm{T}$ cells to CD4+CD25+ regulatory $\mathrm{T}$ cells by TGF-beta induction of transcription factor Foxp3. J Exp Med. 2003; 198:1875-1886.

46. Fantini MC, Becker C, Monteleone G, Pallone F, Galle PR, Neurath MF. Cutting edge: TGF-beta induces a regulatory phenotype in $\mathrm{CD} 4+\mathrm{CD} 25-\mathrm{T}$ cells through Foxp3 induction and down-regulation of Smad7. J Immunol. 2004; 172:5149-5153.

47. Edinger M, Hoffmann P, Ermann J, Drago K, Fathman CG, Strober S, Negrin RS. CD4+CD25+ regulatory T cells preserve graft-versus-tumor activity while inhibiting graftversus-host disease after bone marrow transplantation. Nat Med. 2003; 9:1144-1150.

48. Schneidawind D, Pierini A, Negrin RS. Regulatory T cells and natural killer $T$ cells for modulation of GVHD following allogeneic hematopoietic cell transplantation. Blood. 2013; 122:3116-3121.

49. Trzonkowski P, Bieniaszewska M, Juscinska J, Dobyszuk A, Krzystyniak A, Marek N, Mysliwska J, Hellmann A. First-in-man clinical results of the treatment of patients with graft versus host disease with human ex vivo expanded CD4+CD25+CD127- T regulatory cells. Clin Immunol.
$2009 ; 133: 22-26$

50. Koreth J, Matsuoka K, Kim HT, McDonough SM, Bindra B, Alyea EP 3rd, Armand P, Cutler C, Ho VT, Treister NS, Bienfang DC, Prasad S, Tzachanis D, et al. Interleukin-2 and regulatory $\mathrm{T}$ cells in graft-versus-host disease. N Engl J Med. 2011; 365:2055-2066.

51. Kemper C, Atkinson JP. T-cell regulation: with complements from innate immunity. Nat Rev Immunol. 2007; 7:9-18.

52. Sutavani RV, Bradley RG, Ramage JM, Jackson AM, Durrant LG, Spendlove I. CD55 costimulation induces differentiation of a discrete $\mathrm{T}$ regulatory type 1 cell population with a stable phenotype. J Immunol. 2013; 191:5895-5903.

53. Baecher-Allan C, Wolf E, Hafler DA. MHC class II expression identifies functionally distinct human regulatory T cells. J Immunol. 2006; 176:4622-4631.

54. Andersson J, Tran DQ, Pesu M, Davidson TS, Ramsey H, O'Shea JJ, Shevach EM. CD4+ FoxP3+ regulatory T cells confer infectious tolerance in a TGF-beta-dependent manner. J Exp Med. 2008; 205:1975-1981.

55. Rubtsov YP, Rasmussen JP, Chi EY, Fontenot J, Castelli L, Ye X, Treuting P, Siewe L, Roers A, Henderson WR Jr, Muller W, Rudensky AY. Regulatory T cell-derived interleukin-10 limits inflammation at environmental interfaces. Immunity. 2008; 28:546-558.

56. Wing K, Onishi Y, Prieto-Martin P, Yamaguchi T, Miyara M, Fehervari Z, Nomura T, Sakaguchi S. CTLA-4 control over Foxp3+ regulatory $\mathrm{T}$ cell function. Science. 2008; 322:271-275.

57. Cao X, Cai SF, Fehniger TA, Song J, Collins LI, PiwnicaWorms DR, Ley TJ. Granzyme B and perforin are important for regulatory $\mathrm{T}$ cell-mediated suppression of tumor clearance. Immunity. 2007; 27:635-646.

58. Boenisch O, Lopez M, Elyaman W, Magee CN, Ahmad U, Najafian N. Ex vivo expansion of human Tregs by rabbit ATG is dependent on intact STAT3-signaling in CD4(+) $\mathrm{T}$ cells and requires the presence of monocytes. Am J Transplant. 2012; 12:856-866.

59. Mahmud D, Nicolini B, van den Dries L, Mahmud N, Arpinati M, Rondelli D. Human CD4(+)CD25(+) Cells in Combination with CD34(+) Cells and Thymoglobulin to Prevent Anti-hematopoietic Stem Cell T Cell Alloreactivity. Biol Blood Marrow Transplant. 2011; 17:61-68.

60. Simon T, Opelz G, Weimer R, Wiesel M, Feustel A, Ott $\mathrm{RC}$, Susal C. The effect of ATG on cytokine and cytotoxic T-lymphocyte gene expression in renal allograft recipients during the early post-transplant period. Clin Transplant. 2003; 17:217-224.

61. Osorio F, Fuentes C, Lopez MN, Salazar-Onfray F, Gonzalez FE. Role of Dendritic Cells in the Induction of Lymphocyte Tolerance. Front Immunol. 2015; 6:535.

62. Miroux C, Morales O, Carpentier A, Dharancy S, Conti F, Boleslowski E, Podevin P, Auriault C, Pancre V, Delhem 
N. Inhibitory effects of cyclosporine on human regulatory T cells in vitro. Transplant Proc. 2009; 41:3371-3374.

63. Bocian K, Borysowski J, Wierzbicki P, Wyzgal J, Klosowska D, Bialoszewska A, Paczek L, Gorski A, Korczak-Kowalska G. Rapamycin, unlike cyclosporine A, enhances suppressive functions of in vitro-induced CD4+CD25+ Tregs. Nephrol Dial Transplant. 2010; 25:710-717.

64. Hoegh-Petersen M, Amin MA, Liu Y, Ugarte-Torres A, Williamson TS, Podgorny PJ, Russell JA, Grigg A, Ritchie D, Storek J. Anti-thymocyte globulins capable of binding to $\mathrm{T}$ and $\mathrm{B}$ cells reduce graft-vs-host disease without increasing relapse. Bone Marrow Transplant. 2013; 48:105114.
65. Ruzek MC, Neff KS, Luong M, Smith KA, Culm-Merdek K, Richards SM, Williams JM, Perricone M, Garman RD. In vivo characterization of rabbit anti-mouse thymocyte globulin: a surrogate for rabbit anti-human thymocyte globulin. Transplantation. 2009; 88:170-179.

66. Xystrakis E, Bernard I, Dejean AS, Alsaati T, Druet P, Saoudi A. Alloreactive CD4 T lymphocytes responsible for acute and chronic graft-versus-host disease are contained within the CD45RChigh but not the CD45RClow subset. Eur J Immunol. 2004; 34:408-417. 